\title{
Epstein-Barr Virus: Diseases Linked to Infection and Transformation
}

\author{
Hem C. Jhat, Yonggang Pei and Erle S. Robertson* \\ Department of Otorhinolaryngology-Head and Neck Surgery and Tumor Virology Program, Abramson Cancer Center, \\ Perelman School of Medicine at the University of Pennsylvania, Philadelphia, PA, USA
}

\section{OPEN ACCESS}

Edited by:

Akio Adachi,

University of Tokushima, Japan

Reviewed by:

Kenneth Kaye,

Brigham and Women's Hospital, USA Benjamin E. Gewurz,

Brigham and Women's Hospital, USA

Masanao Murakami,

Kochi Gakuen College, Japan

*Correspondence:

Erle S. Robertson

erle@upenn.edu

${ }^{\dagger}$ Present address: Hem C. Jha,

Centre for Biosciences and Biomedical Engineering, Indian Institute of Technology Indore, Indore,

India

Specialty section:

This article was submitted to

Virology,

a section of the journal

Frontiers in Microbiology

Received: 10 July 2016

Accepted: 26 September 2016

Published: 25 October 2016

Citation:

Jha HC, Pei $Y$ and Robertson ES (2016) Epstein-Barr Virus: Diseases Linked to Infection and Transformation.

Front. Microbiol. 7:1602. doi: 10.3389/fmicb.2016.01602
Epstein-Barr virus (EBV) was first discovered in 1964, and was the first known human tumor virus now shown to be associated with a vast number of human diseases. Numerous studies have been conducted to understand infection, propagation, and transformation in various cell types linked to human diseases. However, a comprehensive lens through which virus infection, reactivation and transformation of infected host cells can be visualized is yet to be formally established and will need much further investigation. Several human cell types infected by EBV have been linked to associated diseases. However, whether these are a direct result of EBV infection or indirectly due to contributions by additional infectious agents will need to be fully investigated. Therefore, a thorough examination of infection, reactivation, and cell transformation induced by EBV will provide a more detailed view of its contributions that drive pathogenesis. This undoubtedly expand our knowledge of the biology of EBV infection and the signaling activities of targeted cellular factors dysregulated on infection. Furthermore, these insights may lead to identification of therapeutic targets and agents for clinical interventions. Here, we review the spectrum of EBV-associated diseases, the role of the encoded latent antigens, and the switch to latency or lytic replication which occurs in EBV infected cells. Furthermore, we describe the cellular processes and critical factors which contribute to cell transformation. We also describe the fate of B-cells and epithelial cells after EBV infection and the expected consequences which contribute to establishment of viral-associated pathologies.

Keywords: EBV, latency, lytic, transformation, B-cell, epithelial cell, cancer, infection

\section{INTRODUCTION}

\section{Viral Infections in Cancer}

Worldwide cancer is one of the leading causes of death (de Martel et al., 2012). In 1990, studies suggested that approximately $16 \%$ of all cancers are associated with infectious agents (Pisani et al., 1997). However, less developed regions range greater than $20 \%$ compared to the more developed regions which shows that approximately $9 \%$ of all cancers in the population are associated with infectious agents (de Martel et al., 2012). Interestingly, reports from 2002 estimates suggest that infectious agents are linked to $18 \%$ of the global burden of cancer (Parkin, 2006). In the same year, the share of infection associated cancers in less developed regions were more than $26 \%$ compared to $8 \%$ in more developed regions (Parkin, 2006). Further a study in 2008 suggested that these infection-associated cancers attributed to $33 \%$ of cancers in sub-Saharan Africa (de Martel et al., 2012). This study also showed that $30 \%$ of cancers associated with infections occurred in people 
younger than 50 years of age (de Martel et al., 2012), and strongly suggested that they are causative or major drivers in the process. In 2010, approximately 8 million deaths were linked to cancer. Surprisingly, and worrisome the rate of death due to cancer has continued to increase by $2 \%$ per year (Lozano et al., 2012). Thus, assessing the risk factors or causative agents of cancer is of extreme importance for future prevention strategies.

\section{EBV Types and Infection}

Epstein-Barr virus (EBV) was first discovered in cultured tumor cells derived from a biopsy of a Burkitt's lymphoma (BL) patient in 1964 (Burkitt, 1969). Alone, EBV accounts for 0.5-2\% cancers based on geographical regions (Epstein et al., 1964; Khan and Hashim, 2014), and recent analysis indicates that $1.8 \%$ of all cancer deaths in 2010 were associated with EBV (Khan and Hashim, 2014). EBV was identified as the first human tumor virus as it was involved initially linked to $\mathrm{BL}$, and since then several other types of cancers (Thompson and Kurzrock, 2004). There are two different EBV types which are commonly known as types 1 and 2 (Cho et al., 1999). It has been shown that the genomes of these two EBV types are very similar except for regions of the EBNA genes (Dambaugh et al., 1984). Tzellos et al. (2014) demonstrated that the greater ability of type 1 EBV infection to induce B cell proliferation is likely due to superior expression of EBNA2 which consequently leads to the upregulation of LMP1 and cellular CXCR7. Notably, the percent association of EBV varies in different diseases and may have consequences toward the aggressivity of the associated cancers.

\section{EBV ASSOCIATED DISEASES}

\section{B-Cell Associated Diseases Burkitt's Lymphoma}

Geographic regions like equatorial Africa and Papua New Guinea have holoendemic malaria and those are 100\% EBV positive (Kelly and Rickinson, 2007). This is classified as endemic BL as typically represents as a jaw or abdominal tumor in children's (Valenzuela-Salas et al., 2010). However, western countries have lower incidence rates and lower association with EBV. Approximately, 15-20\% BL tumors were EBV positive (Kelly and Rickinson, 2007). Hence, it is possible that chronic immune stimulation from the burden of pathogenic agents may increase the incidence of BL (Engels, 2007). Interestingly, AIDS-BL, was shown to be very common among HIV-infected individuals with a wide range of CD4 counts, and usually appears as one of the symptoms of AIDS with $30-40 \%$ of these BL-tumors are positive for EBV. Typically, the majority of BLs carry a reciprocal translocation that places the $c$-myc gene under the control of either the heavy- or light-chain immunoglobulin (IgH or IgL) loci (Brady et al., 2007). Therefore, c-myc deregulation represents an essential defining feature of BL pathogenesis (Kelly and Rickinson, 2007). Interestingly, EBV genomes are found in neoplastic cells of endemic Burkitt's lymphoma (eBL) patients (Wright, 1971; Tao et al., 1998). Endemic BL has been associated with endemic malaria (de-The, 1985). However, further studies are needed to effectively determine the contributions of malaria infection to development of EBV associated endemic BLs.

\section{Post-transplant Lymphoproliferative Disease (PTLD) and Central Nervous System Lymphoma (CNS Lymphoma)}

More than $90 \%$ of B-cells in early onset and $60-80 \%$ in late onset of post-transplant lymphoproliferative disease (PTLD) are EBV positive (Petrara et al., 2015). Moreover, early onset PTLDs are either polyclonal or oligoclonal, while most of late onset PTLDs are truly monoclonal (Carbone et al., 2008). PTLD occurs after transplantation or primary EBV infection, acquired from the donor following transplantation (Allen et al., 2002). As all the major EBV latent antigens are extensively expressed in PTLD, this strengthens the contributory role for EBV infection and viral gene expression in PTLD pathogenesis (Odumade et al., 2011). Interestingly, 50\% of PTLD's are deficient in a functional B-cell receptor (BCR), which is essential for B-cell survival (Bechtel et al., 2005). Therefore, EBV can protect these cells from death by blocking apoptosis even in the absence of antigen stimulation (Spender and Inman, 2011).

MicroRNAs refer to a group of small non-coding RNA molecules with crucial influences on specific cancers (Macfarlane and Murphy, 2010). By detecting the EBV and cellular microRNAome in PTLD (Forte et al., 2012; Harris-Arnold et al., 2015), studies showed that there are two different microRNA profiles identified in primary central nervous system posttransplant lymphoproliferative disorders (pCNS PTLD). First, EBV microRNAs interacts with the cellular microRNAome similarly to that of EBV-associated systemic PTLD and the second could be limited to the immunological functions associated with the central nervous system (Moscato et al., 2013; Fink et al., 2014). Although, a limited expression of latency genes is also seen in EBV associated systemic PTLD, based on promoter utilization it is still considered to be latency III (Fink et al., 2014). A higher frequency of EBV in pCNS PTLD compared to systematic PTLD may result in pathological differences (Cavaliere et al., 2010). Also, AIDS-related CNS lymphomas are derived from germinal center B-cells and are always EBV positive (Bibas and Antinori, 2009). These CNS lymphomas contain immunoblastic and large non-cleaved lymphomas (Taylor et al., 1978). EBV infection in PTLD exploits several strategies to ensure persistent infection, namely, prevention from death of infected cells, enhancement of their proliferation to maintain the infected reservoir, and escape from host immune system (Hsieh et al., 1999; Tanner and Alfieri, 2001).

\section{Hodgkin Lymphoma (HD)}

In 1966, MacMahon suggested that Hodgkin's disease might be due to an infectious agent (Flavell and Murray, 2000). Later, the infectious agent EBV has been detected by high antibody titers in patients with Hodgkin's disease when compared with other lymphomas patients (Alexander et al., 2003). EBV positivity in $\mathrm{HD}$ is extremely high in some geographical areas (Flavell and Murray, 2000). There are several critical factors on which association of EBV with Hodgkin's disease seems to depend, 
which include geography, histological subtype, sex, ethnicity, and age (Flavell and Murray, 2000). Reports have suggested that in less developed regions, 90\% of childhood Hodgkin lymphoma (HD) and approximately $60 \%$ of adult HDs are EBV positive (Oh and Weiderpass, 2014). Earlier Weniger and Kuppers (2016), reviewed that LMP1 and LMP2A are expressed at high levels in the Reed-Sternberg cells, and activate pathways, namely NF$\mathrm{kB}$ and PI3K which are also highly activated in EBV-negative HL. However, the role that EBV plays in their pathogenesis is still not fully understood. Contrary to this, gastrointestinal involvement is an exceptionally rare incident in HD and might occur as infiltration from mesenteric lymph nodes (Issa and Baydoun, 2009). Few cases have been described that demonstrate EBV positive primary gastrointestinal HD (Cardona et al., 2012). Initial symptoms are restricted to extranodal tissue and are more uncommon in HD compared to NHLs. Few cases have been described which demonstrate EBV positive primary gastrointestinal HD (Cardona et al., 2012). The majority of these cases were linked to Crohn's disease and immunosuppression (Lewis, 2012). A probable hypothesis given for EBV infected HL in children and older individuals was primary infection and a weak immune response toward EBV latent genes, respectively (Grywalska and Rolinski, 2015). Furthermore, delayed primary infection can contribute to EBV associated HL in young adults (Grywalska and Rolinski, 2015).

\section{Non-Hodgkin Lymphoma (NHL)}

Eighty five to ninety percentage of Non-Hodgkin's lymphomas (NHLs) arises from B lymphocytes followed by $\mathrm{T}$ lymphocytes and natural killer (NK) lymphocytes (Diaz et al., 1993). Lymph nodes are the primary site for NHL, however, it can occur in almost any tissue (Krol et al., 2003). NHL attributed approximately $5.1 \%$ of all cancer cases and $2.7 \%$ of all cancer deaths worldwide (Sharma et al., 2014). Geographically, NHL presence is predominantly observed in North America, Europe, Oceania, and several African countries (Hossain et al., 2014). There are several risk factors for NHL including sex, age, HIV/AIDS, familial aggregation, autoimmune conditions, rheumatoid arthritis, celiac disease, systemic lupus erythematosus (Ekstrom Smedby et al., 2008). There are also several microbial agents shown to be associated with NHL with one of the prominent one being EBV (Carbone et al., 2008).

\section{EBV-Associated Lymphomas in Congenital Immunodeficient Individuals}

First, these disorders are a result of an inherited immunodeficiency known as X-linked lymphoproliferative disorder (Marsh and Filipovich, 2011). Second, some lymphomas are related to use of immunosuppressive drugs given to transplant recipients. Third, they are due to immunosuppression from HIV infection and referred to as AIDS-related lymphoproliferative disorders (Kanakry and Ambinder, 2013). Typically the gene expression patterns in these disorders show EBV latency III (Thompson and Kurzrock, 2004). Furthermore, EBVassociated lymphomas in the immunocompromised hosts are very aggressive in nature and extremely difficult to treat (Cohen et al., 2009).

\section{Oral Hairy Leukoplakia}

Oral hairy leukoplakia (OHL) presents as white patches, which are observed normally on the lateral surfaces of the tongue (Komatsu et al., 2005). The presence of EBV is detected in the tissues and blood due to chronic immunosuppression like HIV infection (De Paschale and Clerici, 2012). Additionally, patients who receive organ and bone marrow transplant have also been shown to develop these symptoms (Allen et al., 2002). Therefore ORL correlates with ongoing immune suppression due to HIV infection or treatment post-transplantation to prevent rejection.

\section{Epithelial Cells Related Cancers Nasopharyngeal Carcinoma (NPC)}

Nasopharyngeal cancer (NPC) is an invasive malignancy rarely found in western countries, however, high prevalence is observed in populations like, South-Eastern Asia and Northern Africa, mainly in Southern China, Singapore, Malaysia, and NorthEastern India (Torre et al., 2015). The majority of NPC tumors are found to be positive for EBV infection (Niedobitek, 2000). Establishment of a latent and transforming infection in epithelial cells are potentially an important causative factor for the development of NPC (Tsao et al., 2015). Studies suggest that about two thirds of NPC cases present as type II EBV latency, in which viral latency antigens are less immunogenic, but could still be targeted by specific cytotoxic T-lymphocytes (Rooney et al., 2014). Predominantly, EBNA1 and LMP1 are expressed in the majority of EBV-positive NPCs (Brooks et al., 1992).

There are three types of NPC as classified by World Health Organization (WHO). Type one is characterized as keratinizing squamous cell carcinoma (SCC), type two is non-keratinizing carcinoma, and type three is undifferentiated carcinoma (Pathmanathan et al., 1995). Usually, types 1 and 2 have been associated with western population (Cao et al., 2011). Type three which is predominantly associated with EBV latent infection have been associated with China and some other Asian countries (Cao et al., 2011). Due to unusual lymphocytic infiltration, type three NPC is referred as lymphoepithelioma of the nasopharynx, and reports have suggested that EBV particles through cell-cell contact can be transferred from lymphoid cells to nasopharynglial epithelial cells (Chang et al., 1999). A very high-grade dysplastic lesions of the nasopharynx and invasive NPC combined can suggest that EBV may have the potential to drive neoplastic transformation of nasopharyngeal epithelial cells and facilitate the clonal expansion of malignant cells (Young and Dawson, 2014; Tsao et al., 2015).

\section{Gastric Carcinoma (GC)}

Recently various studies reported the presence of EBV in lymphoepigastric adenocarcinomas (Shibata et al., 1991). However, EBV contribution to pathogenesis in these tumors are still in question. Moreover, there are morphological similarities found between lympho-epithelioma-like gastric carcinoma (GC) and undifferentiated NPC (Young and Dawson, 2014). Hence, it has been hypothesized that in lympho-epithelioma-GC, EBV spreads from the nasopharynx to the stomach (Iizasa et al., 2012). While, in gastric adenocarcinomas EBV may perhaps enter the gastric epithelium without the use of a receptor (Thompson 
and Kurzrock, 2004). Recently, Chen et al. (2015) showed that all gastric mucosa samples from healthy populations were EBV RNA-negative, but interestingly EBV-positivity was found in $46 \%$ of patient tissues with gastritis. These patterns demonstrates that EBV infection may lead to induction of persistent gastric mucosa inflammation and subsequent carcinogenesis (Chen et al., 2015). Cancer Genome Atlas Research Network (2014), the cancer genome atlas research network characterized the genetics of EBV- vs. EBV + GC, and interestingly found distinct mutations and epigenetic profiles in EBV+ GC cases. They demonstrated that EBV+ GC have recurrent PIK3CA mutations, high DNA hypermethylation, and also amplification of JAK2, CD274, and PDCD1LG2 (Cancer Genome Atlas Research, 2014).

\section{EBV LATENT INFECTION OF B-CELLS}

Epstein-Barr virus is perhaps best known for its ability to immortalize human primary B-lymphocytes in culture. A number of B-cell malignancies are associated with EBV infection, including eBL, classical Hodgkin lymphoma (cHL), diffuse large B-cell lymphoma (DLBCL), and AIDS-related lymphoma (Vockerodt et al., 2015). EBV is also found in NK/Tcell lymphoma and several epithelial malignancies like GC and $\mathrm{NPC}$, and has potent B-cell transforming activity in vitro (Pope et al., 1968). Also, mimics B cell proliferative and survival signaling, which allows it to replicate its genome while remaining latent and immune-silent in the host B-cells, thus establishing lifelong persistence (Young and Rickinson, 2004; Cesarman and Mesri, 2007). Most EBV infection is asymptomatic, but EBV manipulation of host cell systems for latent persistence can lead to oncogenesis. Primary infection is usually asymptomatic or causes infectious mononucleosis (IM; Figure 1; Henle et al., 1968). After primary infection, EBV resides mainly in the long-lived memory $\mathrm{B}$ cells of infected individuals (Figure 1), but how EBV gets there is still a major unanswered question.

Different transcription programs are established in different tissues which maintains lifelong EBV infection. Since similar transcriptional programs are found in EBV cancers, the pattern of latency which determines the EBV genes expressed is a key component of the puzzle to understanding the role of EBV antigens in inducing cancers (Kutok and Wang, 2006; Cesarman and Mesri, 2007). The B-cell malignancies express the established latent gene transcription patterns during EBV infection and the related EBV antigens which contribute to the oncogenic process. This is likely linked to the agrressivity of the cancer, the response and recurrance of the malignancies suggesting that these viral antigens are important in driving these viral associated cancers.

Latency I (Lat I) program is characterized by the expression of EBNA1, EBERs, BARTs, and BART microRNAs (Marquitz et al., 2014). EBNA1, the only expressed viral protein in latent infection, tags the EBV episome to the host chromosome, thus allowing it to be segregated and retained during cell division (Frappier, 2012b). Furthermore, EBNA1 is essential for lymphoma survival by preventing cell death (Kirchmaier and Sugden, 1997). Characteristically, in Burkitt's lymphoma (BL), none of the growth-promoting latent genes are expressed except the latent protein EBNA1 (Gregory et al., 1990). Although, the involvement of EBV in $\mathrm{BL}$ is supported by high frequency of tumors that carry the virus in endemic areas (98\%), and the

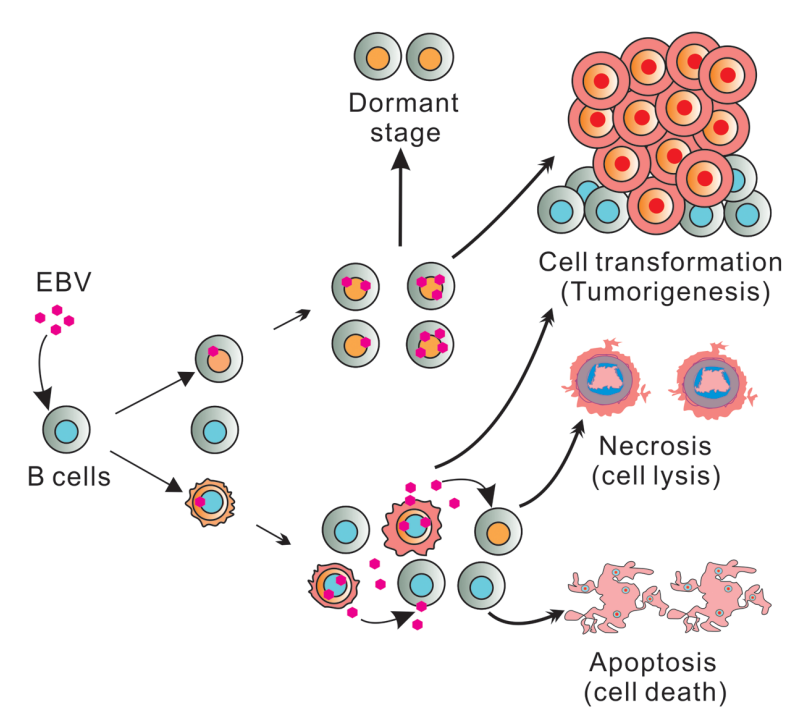

B-lymphocytes

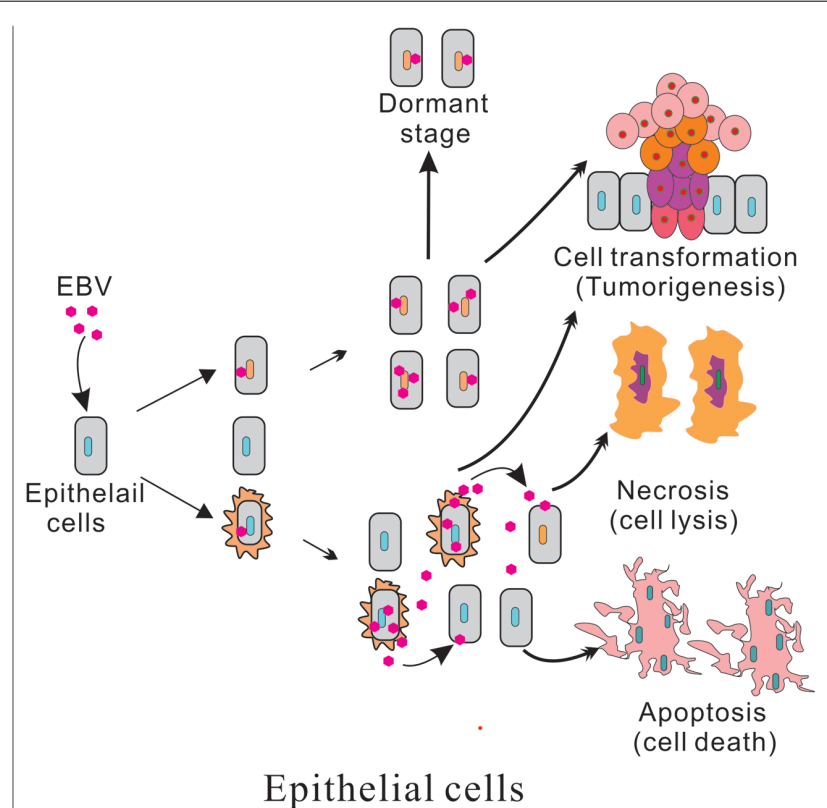

FIGURE 1 | (Left) Represents B-lymphocytes infection and (Right) epithelial cell infection. Epstein-Barr virus (EBV) infected B-lymphocytes and epithelial cells have pools of uninfected and infected cells. Further, some cells produce infectious virus which can infect new cells. The remaining cells will die through apoptosis and necrosis. A portion of the infected cells are transformed and leads to tumorigenesis through cell transformation. Some infected cells are also switched to a dormant stage and can be activated or reactivated when conditions are favorable for lytic replication. 
presence of clonal EBV in all the tumor cells (de-The, 1985; Gulley et al., 1992), it is still not completely understood how EBNA1 participates in tumorigenesis, a multistep process that occurs over a long period of time.

Latency II (Lat II) is characteristic of NPC, HD, ReedSternberg (RS) tumor cells, and EBV-infected $\mathrm{T}$ and NK lymphoma cells (Mesri et al., 2014). In addition to EBNA1, LMP1, and LMP2A are also viral antigens expressed in this latency program (Mesri et al., 2014). These two EBV oncogenes mimic key survival and proliferative signals in B-cells (Mosialos et al., 1995). To be specific, LMP1 mimics a constitutively active CD40 receptor (Mosialos et al., 1995), while LMP2A is able to mimic signaling via activated $\mathrm{B}$ cell Ig receptors depending on its tyrosine-based activation motif (ITAM; Merchant et al., 2000). The first recognition of an association between EBV and Hodgkin's disease came from the observation that IM is a risk factor for this form of lymphoma (Flavell and Murray, 2000). Subsequently, immunoglobulin mutations and the data on viral gene expression independently support the idea that Hodgkin's disease arises from an EBV-infected germinal-center B cell (Kuppers and Rajewsky, 1998).

The associated interaction between EBV and epithelial cells is poorly understood compared to B-cells. It has been shown that infection and replication of the virus usually happens in epithelial cells prior to infection of B cells (Shannon-Lowe et al., 2009). Recently, EBV replication was shown in tongue epithelium, hypothesizing that tongue could be the source of EBV and secreted into saliva (Herrmann et al., 2002). Although, OHL is well-known for productive EBV replication in upperlayer epithelial cells which undergoing terminal differentiation, apoptosis, and desquamation (Walling et al., 2001). All these activities clearly demonstrated that EBV replication in vivo is derived upon the differentiation state of the epithelial cells (Pegtel et al., 2004). Moreover, proper latency in EBV infected epithelial cells is mainly described in NPC and GC (Iizasa et al., 2012). NPC has been reported to be the expression of EBERs, BARTs RNA, EBNA1, LMP2, and LMP1 (Iizasa et al., 2012).

Latency III (Lat III) or growth program is characteristic of EBV-infected B-lymphocytes proliferating as long-term lymphoblastoid cell lines (LCLs) in cell culture. In this pattern, EBV expresses six nuclear antigen proteins (EBNA1, 2, 3A, 3B, $3 \mathrm{C}$, and LP), two latent infection integral membrane proteins (LMP1 and LMP2A, 2B) in addition to the BARTs, EBERs, and miRNAs (Middeldorp et al., 2003; Thompson and Kurzrock, 2004; Bajaj et al., 2007; Hislop et al., 2007; Saha and Robertson, 2011). The expressed latent proteins play important roles by regulating cell cycle, cell proliferation and contribute to the oncogenic process and both latency II and III patterns drive oncogenesis in B- and epithelial cells (Cesarman and Mesri, 2007). Lymphomas expressing EBV latency III program typically develop in immunodeficient individuals including AIDS and transplant patients, while EBV lymphomas and other cancers in immunocompetent hosts will typically display latency I or II patterns (Kutok and Wang, 2006; Cesarman and Mesri, 2007).

A Latency 0 (Lat 0) pattern has also been described where only the EBV-encoded ncRNAs which include EBERs and BARTs are transcribed, and no viral proteins are expressed (ThorleyLawson, 2001; Shaknovich et al., 2006). The infection status was observed in resting memory B cells. Therefore, the lack of EBV protein expression helps these cells to evade $\mathrm{T}$ cells recognition, but it is still unknown how viral proteins are regulated in this pattern, and what kind of cellular transcription factors are involved in the truly latent cells.

\section{EBV NUCLEAR ANTIGENS AND THEIR CONTRIBUTION TO ONCOGENESIS}

\section{EBNA1}

Epstein-Barr virus nuclear antigen 1 (EBNA1) was the first EBV protein detected and is expressed during both EBV latent and lytic infection (Reedman and Klein, 1973). EBNA1 is the only protein required for the persistence of EBV genomes through contribution to both the replication and mitotic segregation of the viral genome (Frappier, 2012b). Additional evidence suggests that EBNA1 is involved in regulation of viral and cellular gene expression (Pfeffer et al., 2004). For example, it is essential for lymphoma survival by preventing cell death (Kirchmaier and Sugden, 1997). EBNA1 induces survivin protein expression and activates its transcription activity by its Sp1 site at the promoter. The up-regulation of survivin expression will suppress cell apoptosis by inhibiting the caspase pathways in EBV-positive cells (Lu et al., 2011). EBNA1 can also induce genomic instability, including DNA damage response (DDR), chromosomal aberrations and DNA doublestrand breaks (DSBs), by regulating RAG-1 and RAG-2 and increasing reactive oxygen species (ROS) through activating the transcription activity of $\mathrm{NOX} 2 / \mathrm{gp} 91^{\text {phox }}$, a catalytic subunit of NADPH oxidase (Tsimbouri et al., 2002; Gruhne et al., 2009; Maynard et al., 2009). A recent study shows that phosphorylation of EBNA1 serine 383 by ERK2 is crucial for EBNA1-mediated transactivation (Noh et al., 2016). In addition, EBNA1 inhibits the expression of the protein tyrosine phosphatase receptor kappa (PTPRK), a TGF- $\beta$ target gene, and helps the survival and growth of HD cells (Flavell et al., 2008). In NPC, EBNA1 could regulate cell metastasis and migration by increasing the expression and nuclear localization of $\mathrm{Nm} 23-\mathrm{H} 1$ which is involved in metastases (Murakami et al., 2005; Cao et al., 2012). EBNA1 also activates transcription activity of AP-1, and further enhances the expression of its target protein vascular endothelial growth factor (VEGF) in NPC cells, which suggests EBNA1 may contribute to angiogenesis and metastasis of NPC (O’Neil et al., 2008). EBNA1 can disturb PML nuclear bodies and then inhibit malignant transformation, which may be important for the development of NPC (Sivachandran et al., 2008). Therefore, a large body of evidence has shown that EBNA1 is associated with several types of cancer through dysregulation of multiple signaling pathways.

\section{EBNA2}

Epstein-Barr virus nuclear antigen 2 (EBNA2) is one of the initial latent viral genes expressed during EBV infection. EBNA2 initiates the transcription of a cascade of primary and secondary target genes through activation of several viral and cellular 
genes (Maier et al., 2006). These changes eventually regulates the activation of the resting $B$ cell, through the cell cycle inducing proliferation of growth transformed cells (Spender et al., 1999). EBNA2 is a nuclear phosphoprotein that mimics intracellular cleaved Notch1 and associates with RBP-Jk to activate the expression of Notch1 target genes (Hofelmayr et al., 2001), and deregulated Notch signaling is known to drive non-viral lymphoid malignancies (Kaiser et al., 1999). EBNA2 is also able to deregulate expression of c-MYC, further increasing cell proliferation by up regulating cyclin Ds and $\mathrm{E}$, as well as downregulation of CDK2 inhibitors such as p21CIP1 and p27KIP1 (Kaiser et al., 1999). EBNA2 also downregulates the expression of $\mathrm{Bcl} 6$, a master regulator of germinal center differention, suggesting a key role of EBNA2 in B cell lymphomagenesis (Boccellato et al., 2007). A recent study showed that the overall survival of patients with EBNA2-positive DLBCL was dramatically poorer than patients with EBNA2-negative DLBCL, suggesting an important role for EBNA2 in lymphoma development (Stuhlmann-Laeisz et al., 2016).

\section{The EBNA3 Family of Proteins}

Epstein-Barr virus nuclear antigen 3 (EBNA3) is a family of three latency-associated proteins, which includes EBNA3A, EBNA3B, and EBNA3C. They were first identified in latently infected $B$ cell cultures, and appear to be critical for EBV persistence and B-cell lymphomagenesis (Whitehurst et al., 2015). The EBNA3 family of proteins share approximately $30 \%$ sequence homology, and are all expressed during the latent phase of EBV infection of primary B-cells and in EBV-associated tumors of immunocompromised cells. However, only EBNA3A and EBNA3C are essential for viral transformation of B-lymphocytes, and all appear to significantly contribute to maintaining the viability of transformed cells, suggesting an important role in oncogenesis (Tomkinson et al., 1993). EBNA3C has been reported to interact with many cellular factors (Robertson et al., 1995; Choudhuri et al., 2007; Saha et al., 2011, 2015; Banerjee et al., 2013, 2014; Jha et al., 2013a, 2014, 2015a,b,c). One of these cellular antigens is RBP-JK, which binds to all the EBNA3 proteins (Robertson et al., 1995, 1996). EBNA3C also binds with Nm23-H1 and reverses its ability to induce cell migration (Subramanian et al., 2001), and targets cell-cycle checkpoints by engaging the SCF (Skp2, Cullin, F-Box)ubiquitin ligase complex that can also lead to proteasomal degradation of the retinoblastoma tumor suppressor protein which demonstrates one of the mechanisms of oncogenesis induced by EBV through the EBNA3 family of proteins (Knight et al., 2005).

There are two important phenomenon in the process of EBV induced oncogenesis described through several cellular players in this review. We have utilized Ingenuity Pathway Analysis (IPA) software, a product of Qiagen, Redwood City, CA, USA. The available database included cellular players that are significantly associated ( $p$-value is $\sim 10^{-13}$ ) with transformation and proliferation of tumor cell lines ( $p$-value is $\sim 10^{-12}$ ) (Figure 2). Our lab and others have demonstrated that EBNA1,

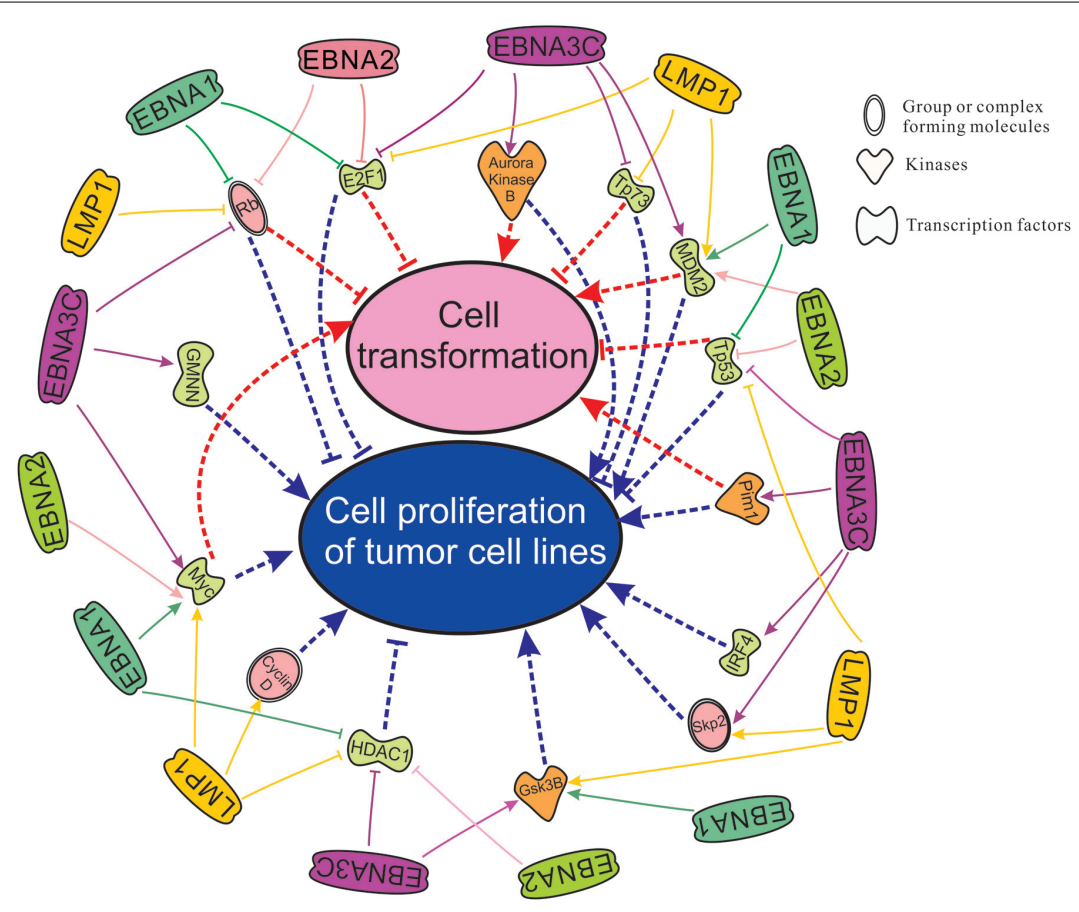

FIGURE 2 | Cell transformation and cell proliferation of tumor cell lines as mapped using the IPA software which demonstrates significant association with major cellular pathways. Here we have groups or complexes formed with cellular molecules including Rb, Skp2, CyclinD, the transcription factors E2F1, Tp73, Mdm2, Tp53, IRF4, Myc, HDAC1 and GMNN (Geminin), and kinases which include Aurora Kinase B, Pim1 and Gsk3B. We have also mapped the known regulation of these cellular antigens and their activities by the essential EBV latent antigens EBNA1, EBNA2, EBNA3C, and LMP1 for transformation and immortalization of EBV-infected cells leading to associated cancers. 
EBNA2, EBNA3C, and LMP1 are potent EBV antigens associated with a number of transcription factors including E2F1, Tp73, MDM2, Tp53, IRF4, Myc, HDAC1, and GMNN (Robertson et al., 1995, 1996; Kaiser et al., 1999; Ma et al., 2000; Plaxco et al., 2000; Zhou et al., 2000, 2005; Knight et al., 2005; Liu et al., 2005; Saridakis et al., 2005; Choudhuri et al., 2007; Ding et al., 2007; Chau et al., 2008; Allday, 2009; Forte and Luftig, 2009; Borestrom et al., 2012; Frappier, 2012a; Accardi et al., 2013; Banerjee et al., 2013; Tursiella et al., 2014; Jha et al., 2015b,c; Saha et al., 2015), kinases including Aurora Kinase B, Pim1, GSK3B (Saha et al., 2011; Jha et al., 2013a; Banerjee et al., 2014; Edwards et al., 2015), and forms complexes with cellular factors whcih includes the tumor suppressor and oncoproteins, Rb, Skp2, and CyclinD (Arvanitakis et al., 1995; Ruf and Sample, 1999; Prathapam et al., 2002; Knight et al., 2005; Choudhuri et al., 2007; Kang et al., 2011; Saha and Robertson, 2011; Saha et al., 2011, 2015; Sun et al., 2015; Figure 2). Cell transformation is regulated through a broad range of interacting partners including Rb, E2F1, Aurora Kinase B, Tp73, Mdm2, Pim1, Tp53, IRF4, Skp2, and Myc (Halazonetis and Kandil, 1991; Lahoz et al., 1994; Hoang et al., 1995; Pirollo et al., 1997; De Laurenzi et al., 1998; Givol et al., 1998; Mochizuki et al., 1999; Lin et al., 2000; Gstaiger et al., 2001; Kanda et al., 2005; Zhang et al., 2005; Xu et al., 2011). Moreover, proliferation of tumor cell lines is associated with dyregulation of the activities of the major cell factors Rb, E2F1, Aurora Kinase B, Tp73, Mdm2, Pim1, Tp53, IRF4, Skp2, Myc, HDAC1, Cyclin D, GSK3B, and GMNN (Wang et al., 2008; Liontos et al., 2009; Karslioglu et al., 2011; Inuzuka et al., 2012; Jo and Ren, 2012; Maddocks et al., 2013; Malinen et al., 2013; Huo et al., 2014; Mikawa et al., 2014; Subramanian et al., 2015). These studies together highlight the importance of EBNA3C and other EBNA proteins in EBV-directed oncogenesis.

\section{The LMP Family of Proteins}

Latent membrane protein-1 (LMP-1) mimics CD40 and its overexpression leads to activation of NF-kB, JNK, PI3K/Akt, and MAPK pathways to promote cellular proliferation (Shair et al., 2007). Additionally, LMP1 activated Bcl 2 blocks apoptosis and participated in cell cycle progression through cyclinD/CDK2 phosphorylation of Rb, and inhibition of p16 and p27 (Everly et al., 2004). Another member of the LMP family, LMP2A diminishes the surface immunoglobulin-mediated lytic cycle reactivation (Bryant and Farrell, 2002). LMP2A also induces the Ras/PI3K/Akt pathway and activates $\mathrm{Bcl}-\mathrm{xL}$ expression to promote B-cell survival (Chen, 2012). A study by Accardi et al. (2013), showed that LMP1 activates the expression of $\Delta \mathrm{Np} 73 \alpha$, a strong antagonist of p53. Furthermore, inhibition of JNK1 through chemicals or silencing, strongly down-regulated $\Delta \mathrm{Np} 73 \alpha$ mRNA levels in LMP1 positive cells (Accardi et al., 2013). At the same time, LMP1 mutants deficient in induction of JNK1 did not induce $\Delta \mathrm{Np} 73 \alpha$ accumulation (Accardi et al., 2013). Interestingly, LMP1 also induces epigenetic changes on the promoter of p73 gene (Accardi et al., 2013). Emerging studies suggest that these epigenetic changes play an important role in carcinogenesis (Ren et al., 2011). Additionally, knockdown through short hairpin RNA depletion of endogenous LMP1 in LCLs suppressed IL-32 expression, a novel proinflammatory cytokine (Lai et al., 2015). Moreover, IL-32 can bind with protein kinase $\mathrm{C} \delta$ inhibiting activation of the Zta promoter. Therefore, knockdown of IL-32 in LCLs induces viral reactivation. However, and surprisingly this has no influence on cell proliferation and apoptosis (Lai et al., 2015).

\section{Non-coding RNAs}

The EBV-encoded nuclear BART RNAs are functional long non-coding RNAs (lncRNAs) (Marquitz et al., 2015). To avoid host immune attack, EBV expression of non-coding RNAs that contribute to growth regulation without an immune response may have implications for immune escape by the virus (Marquitz et al., 2015). A recent RNA-seq analysis by Chen et al. (2005) had showed that more than $99 \%$ of all virally derived polyadenylated transcripts were BARTs in EBV-infected gastric tumors. Another study by Feederle et al. (2011) highlighted the functions of miRNAs in EBV infection as a strategy for allowing synchronous and synergistic expression of genetic elements that contribute to transformation of their target cells.

EBV-encoded small RNAs (EBERs) has been reported as growth-stimulatory and their roles have been confirmed in EBV-mediated B-cell transformation (Yajima et al., 2005). Using genetic engineering approaches by reverse genetics in primary $\mathrm{B}$ cells and in Akata cells the data strongly supports the hypothesis that EBERs have roles in transformation of human primary $B$ cells. However, in vitro studies with deletion mutants have indicated that EBV can transform B-cells without the presence of the EBERs (Jha et al., 2016).

\section{THE SWITCH OF LYTIC INFECTION AND LATENCY}

Typically, two types of EBV infection can be established in different cell types: latent in primary B-cells and lytic in epithelial cells (Figure 1; Amon and Farrell, 2005; Tsurumi et al., 2005). Primary infection is generally asymptomatic. However, primary infection in early adulthood can lead to IM (Odumade et al., 2011). Upon initial infection of cells, EBV briefly undergoes an initial burst of lytic replication that is productive but is aborted and switches to a latent infection (Figure 1; Mansouri et al., 2014). Following this period, EBV becomes strictly latent after the lytic genes are silenced by chromatinization (Penkert and Kalejta, 2011). It is important to note that only a small fraction of the virus infected cells are reactivated during the latent infection state (Figure 1; Rong and Perelson, 2009).

The switch during EBV infection in host cells from latent to lytic form is greatly determined by the cellular transcription factors that regulate the activity of immediate-early (IE) lytic genes, especially BZLF1 and BRLF1 (Adamson et al., 2000). In EBV latently infected cells, multiple cellular factors are necessary for establishment and maintenance of viral latency (Haan et al., 2001). For example, YY1 inhibits BZLF1 and BRLF1 transcription and is important for maintenance of viral latency (Zalani et al., 1997). MEF2D recruits class II histone deacetylases (HDAC) to the BZLF1 gene promoter and inactivates its activity (Gruffat et al., 2002b). Furthermore, Oct-2 and PAX5, two B cell-specific 
transcription factors, have also been shown to be important in promoting EBV latency by negatively regulating the function of the BZLF1 protein (Robinson et al., 2012; Raver et al., 2013). The chromatin structure of the BZLF1 gene promoter (Zp) is also critical for regulating its expression (Chang et al., 2008). $Z p$ is activated by histone acetylation and was shown to be inactivated by DNA methylation (Bryant and Farrell, 2002). These multiple strategies are involved in regulating latency during EBV infection.

Epstein-Barr virus reactivation can be triggered in human cells by either chemical agents or biological stimuli, including TPA, sodium butyrate, HDAC inhibitors, phorbol esters, calcium ionophores, chemotherapeutic agents, BCR engagement, TGF- $\beta$, and hypoxia (Figure 1; Gorres et al., 2014; Kenney and Mertz, 2014). BCR signaling-mediated EBV reactivation is mainly induced through PI3K and PKC that further regulate the activity of the Zp promoter (Goswami et al., 2012). T-cells secreting TGF$\beta$ also triggers EBV reactivation through signaling and induction of BZLF1 gene expression (Fahmi et al., 2000; Inman and Allday, 2000). Hypoxia can also activate EBV lytic infection by enhancing the expression of the immediate early transactivator Zta (Jiang et al., 2006). These factors finally activate the transcription of two lytic transactivators BZLF1 and BRLF1 (Miller et al., 2007). Then the two genes encode antigens induced expression of viral E (early) genes, which are necessary for viral DNA replication, and L (late) genes, such as capsid proteins and glycoproteins (Gruffat et al., 2002a). In most EBV-positive cell lines, the Zta protein, encoded by the BZLF1 ORF, is a major trigger for viral reactivation because its expression alone can induce the reactivation cascade (Speck et al., 1997). This suggests that it is a major switch important for EBV reactivation from latency. Expression of the BRLF1 gene encoding the Rta protein also induces the switch from latent to lytic infection in a subset of EBV-positive cells, particularly epithelial cells. Importantly, EBV reactivation is largely induced by BCR stimulation and plasma cell differentiation (Laichalk and Thorley-Lawson, 2005; Davies et al., 2010). Two cellular proteins, XBP-1 and BLIMP1 , are critical for differentiation of plasma cells (Reimold et al., 2001; Shaffer et al., 2002). Furthermore, the expression of XBP1 in some EBV latently infected cells is sufficient for viral reactivation, and BLIMP-1 could also induce viral lytic cycle in EBV-transformed cells by activating $\mathrm{Zp}$ and $\mathrm{Rp}$ transcription (Vrzalikova et al., 2011).

\section{REACTIVATION OF EBV}

Viral reactivation in an infected host is induced by several key factors (Ye et al., 2011). Chronic interpersonal stress can drive EBV reactivation and replication by weakening the cellular immune system control over viral latency through both autonomic and glucocorticoid pathways (Fagundes et al., 2014). The chronic relationship with stress could be a key psychological feature driving the link between attachment anxiety and EBV reactivation (Fagundes et al., 2014). Also, it has been hypothesized that individuals who have higher attachment anxiety have elevated EBV VCA IgG antibodies compared to lower attachment anxiety (Fagundes et al., 2014).
Typically, EBV-induced cancers containing undifferentiated cells may be due in part to cells dying from lytic EBV infection when they differentiate (Reusch et al., 2015). However, Ntera2 cells, a neuro-epithelial cells can be infected by EBV after differentiation (Jha et al., 2015a). In gastric cancer and NPC cell lines, BLIMP1 is sufficient to induce EBV lytic gene expression (Reusch et al., 2015). Furthermore, the studies showed that BLIMP1 can activate transcription of $\mathrm{Rp}$ over 300 -fold in addition to $\mathrm{Zp}$ at 20- to 50-fold in several epithelial cell lines (Reusch et al., 2015). Reusch et al. (2015) showed that both Zp and $\mathrm{Rp}$ are robustly induced by BLIMP1, and that $\mathrm{Rp}$ is activated greater than $\mathrm{Zp}$ in epithelial cells. Therefore, it is possible that BLIMP1 activation of $\mathrm{Zp}$ is a major mechanism for induction of EBV reactivation in B-cells (Vrzalikova et al., 2011). Therefore, it is speculated that $\mathrm{EBV}$ induced $\mathrm{B}$-cell malignancy are much more responsive to Zp than $\mathrm{Rp}$ (Reusch et al., 2015). Also, deletion of EBER1 or EBER2 had minimal effect on the transformation frequency of primary B-cells or the generations of LCLs by EBV (Wu et al., 2007). Moreover, Gulley and Tang (2008) showed that EBER2 is essential for efficient transformation of B lymphocytes and maximum growth potential of LCLs. Contrary to this, several studies demonstrated that EBERs were not essential for primary infection, viral replication, or B-cell immortalization (Delecluse and Hammerschmidt, 2000). However, EBERs were found to be important for establishment of malignant phenotypes and tumor formation in SCID mice (Yamamoto et al., 2000).

Most of the EBV latent proteins expressed in $\mathrm{Wp}$-restricted or type III latency were oncogenic and might contribute to resistance of EBV-associated lymphomas to chemotherapy (Hui et al., 2014). Further, it was shown that EBV-positive BL cells of type III latency were more resistant to dying by nocodazole or taxol compared to EBV negative or latency I BL cells (Leao et al., 2007). BL cells of Wp-restricted or type III latency were more resistant to treatment with HDAC inhibitors than those of type I latency (Leao et al., 2007).

TERT-induced NOTCH2 activation is regulated through NF$\mathrm{kB}$ (Nickoloff et al., 2002). In addition, pharmacologic inhibition of NOTCH signaling triggers EBV lytic cycle which leads to the death of the EBV-infected cells (Giunco et al., 2015). IRFs are also regulated by EBV and can modulate the expression of both viral and cellular factors that are involved in EBV latency and transformation (Zhang and Pagano, 2001). To date, it is known that IRF-7, IRF-4 and IRF-5 are associated with EBV transformation (Xu et al., 2011). IRF-5, normally a tumor suppressor is highly expressed in EBV transformed cells. Combined with IRF-4, it is involved in EBV-mediated regulation of Toll like receptor 7 (TLR7) activities (Martin et al., 2007). Recently, we have shown that Spi-1/B motif of IRF-4 is critical for its interaction with EBNA3C in EBVinduced B-cell immortalization (Banerjee et al., 2013). We also demonstrated that EBNA3C can stabilize IRF-4, which leads to downregulation of IRF-8 by enhancing its proteasome-mediated degradation (Banerjee et al., 2013). Therefore, we conclude that EBV induces a balanced expression of IRFs during EBV transformation which when deregulated can trigger reactivation. With mutual inhibition and/or activation among oncogenic and tumor suppressor factors, EBV may drive the infected cell to 
apoptosis or proliferation in various microenvironments for the survival of the virus in vivo and this may also have important consequences for viral gene regulation whcih leads to reactivation of a small percentage of infected cells in tumors which are critical for maintaining the cancer phenotype (Zhao et al., 2010).

In LCLs and PBMCs, we have successfully demonstrated that the mitotic protein Aurora kinase B (AK-B) is critical, and regulated through EBNA3C in B-cell transformation (Jha et al., 2013a). In the course of transformation both EBNA3C and AK-B targets several tumor suppressors like p53, p73 and pRB through a mechanism of phosphorylation and ubiquitination (Jha et al., 2015c). Cyclins, specifically Cyclin A, D1, E are also a crucial regulators in B-cell transformation through EBV (Saha et al., 2011). Several studies highlighted the importance of the DDR in EBV induced B-cell transformation (Choudhuri et al., 2007; Jha et al., 2013b, 2014). Briefly, ChK1, ChK2, and $\mathrm{H} 2 \mathrm{AX}$ are critical components of EBV-derived B-cell transformation and are activated during early infection as well as provide a bridge to bypass the host immune system for virus propagation (Choudhuri et al., 2007; Jha et al., 2014).

Studying latent and lytic replication in EBV infected B-cells or epithelial cells is important for determination of the mechanisms which lead to development of EBV-associated diseases. In several studies utilizing primary or immortalized B-cells infected with wild type EBV isolated from BAC clones, we monitored the expression of genes at transcript levels during the early days of infection (Figure 1; Halder et al., 2009; Saha et al., 2011, 2015; Banerjee et al., 2013; Jha et al., 2013a, 2015b,c). Further, we have used several epithelial primary and immortalized cells including primary neurons, Ntera-2, Sh-Sy5Y, and HEK-293 cells (Jha et al., 2015a), and clearly showed that during the initial days of EBV infection the latent gene expression was low, but the lytic gene expression resulted in active virus progeny produced in the culture medium. Furthermore, this active virus progeny was capable of infecting new cells during this early infection period. Therefore, the number of EBV infected cells were greater on day 5 compared to days 1 or 2 (Jha et al., 2015a). Active virus progeny were verified through infection of fresh cells with virus collected from media during early infection (Figure 1). We have also observed that a large percentage of infected cells died during this early period. Previous studies have also suggested that EBV-infected B-cells are transformed to LCLs in a similar manner after and initial period of lytic virus production (Figure 1; Kurth et al., 2000; Carter et al., 2002; Shannon-Lowe et al., 2009). However, investigating the disease-associated cell types will provide further insights which will enhance our understanding of the complexity of EBV-driven pathogenesis in a range of associated chronic diseases.

\section{EBV VIRAL LOAD IN HODGKIN AND NON-HODGKIN}

Epstein-Barr virus viral load in plasma has been used as a marker of tumor burden in patients with sporadic EBV-related lymphoma including B cell, T cell, NK cell, and Hodgkin subtypes (Gulley and Tang, 2010). Interestingly, EBV DNA is detectable ahead of cancer diagnosis, and also the level of its DNA at diagnosis can predict effects and efficacies of therapies (Zhang et al., 2015). These findings strongly suggest that routine plasma evaluation for EBV viral load on initial diagnosis may be important for predicting EBV-related pathogenesis. Whether or not this is transferable to other know tumor viruses is yet to be determined but in this age of microbiome and exchange of genetic information between host and infectious agents it would not be surprising if future diagnostic strategies can be developed using blood serum analysis of nucleic acids signatures to detect levels of infectious agents including viruses like EBV as a routine test for predicting associated pathologies.

\section{TREATMENT OF EBV ASSOCIATED DISEASES}

To date the majority of antiviral agents used against EBV are the acyclic nucleoside analogs Acyclovir or Ganciclovir, which are only efficient during EBV lytic life cycle (Gustafson et al., 1998). Another antiviral Maribavir is active against EBV (Gershburg and Pagano, 2005). However, the mechanism of action is not fully understood. Furthermore, some natural and synthetic compounds, like moronic acid, derivatives of betulinic, glycyrrhizic acids, and flavonoids have been shown to inhibit EBV lytic cycle (Chang et al., 2003; Lin, 2003; Lin et al., 2008). However, their mechanism of actions are not welldefined.

Recently, we have successfully identified several small molecules inhibitors (NSC65381, NSC10010, NSC16553, and NSC1881) that were able to kill virus positive LCLs as well as EBV negative BL cells (Dzeng et al., 2015). We have also demonstrated that $\mathrm{c}-\mathrm{Myc}$ and $\mathrm{NF}-\mathrm{kB}$ are the major signaling molecules targeted through these inhibitors to kill virus positive cells (Dzeng et al., 2015). Earlier, arsenic trioxide (As2O3) and sodium arsenite $(\mathrm{NaAsO} 2)$ were also shown to induce cell death in P3HR1 cells (Zebboudj et al., 2014). Interestingly, this effect was due to reactivation of EBV lytic cycle through induction of the immediate-early proteins Zta and Rta (Ragoczy et al., 1998). There are several studies using a combination of drugs including rituximab, cyclophosphamide, vincristine, doxorubicin, and prednisolone or methotrexate, vincristine, and procarbazine to treat EBV associated patients with greater efficacy (Kuriyama et al., 2014). These combined therapeutic approaches may be a better strategy for future anti-viral therapy as is now becoming the norm in most oncology regimens.

\section{POTENTIAL FUTURE DISCOVERY}

Recently growing evidence suggest that the CRISPER/CAS9 system can be efficiently activated in viral infected cells for editing of viral genomes (Seeger and Sohn, 2014; Yuen et al., 2015). Using this strategy we can precisely destroy the latent promoters of 
EBV which are critical for viral latent infection and so result in loss of transformed phenotype and killing of infected cells. This could be a potential strategy for control of EBV pathogenesis in immunocompromised individuals. Another approach for future exploration is to uncover the complete transcription network of host-EBV interaction. This could be classified as the types of genes at different locations, temporally expressed, and the associated pathologies. One interesting possibility is the utility of EBV in gene therapy. EBV can efficiently infect B-cell and the infected cells circulates in the vascular system. Therefore, EBV may have potential for use as a novel vector to transport of cellular genes to specific anatomical sites as a means of targeted gene therapy.

\section{REFERENCES}

Accardi, R., Fathallah, I., Gruffat, H., Mariggio, G., Le Calvez-Kelm, F., Voegele, C., et al. (2013). Epstein - Barr virus transforming protein LMP-1 alters B cells gene expression by promoting accumulation of the oncoprotein DeltaNp73alpha. PLoS Pathog. 9:e1003186. doi: 10.1371/journal.ppat.10 03186

Adamson, A. L., Darr, D., Holley-Guthrie, E., Johnson, R. A., Mauser, A., Swenson, J., et al. (2000). Epstein-Barr virus immediate-early proteins BZLF1 and BRLF1 activate the ATF2 transcription factor by increasing the levels of phosphorylated p38 and c-Jun N-terminal kinases. J. Virol. 74, 1224-1233. doi: 10.1128/JVI.74.3.1224-1233.2000

Alexander, F. E., Lawrence, D. J., Freeland, J., Krajewski, A. S., Angus, B., Taylor, G. M., et al. (2003). An epidemiologic study of index and family infectious mononucleosis and adult Hodgkin's disease (HD): evidence for a specific association with EBV+ve HD in young adults. Int. J. Cancer 107, 298-302. doi: $10.1002 / \mathrm{ijc} .11156$

Allday, M. J. (2009). How does Epstein-Barr virus (EBV) complement the activation of Myc in the pathogenesis of Burkitt's lymphoma? Semin. Cancer Biol. 19, 366-376. doi: 10.1016/j.semcancer.2009.07.007

Allen, U., Alfieri, C., Preiksaitis, J., Humar, A., Moore, D., Tapiero, B., et al. (2002). Epstein-Barr virus infection in transplant recipients: summary of a workshop on surveillance, prevention and treatment. Can. J. Infect. Dis. 13, 89-99. doi: $10.1155 / 2002 / 634318$

Amon, W., and Farrell, P. J. (2005). Reactivation of Epstein-Barr virus from latency. Rev. Med. Virol. 15, 149-156. doi: 10.1002/rmv.456

Arvanitakis, L., Yaseen, N., and Sharma, S. (1995). Latent membrane protein-1 induces cyclin D2 expression, pRb hyperphosphorylation, and loss of TGFbeta 1-mediated growth inhibition in EBV-positive B cells. J. Immunol. 155, 1047-1056.

Bajaj, B. G., Murakami, M., and Robertson, E. S. (2007). Molecular biology of EBV in relationship to AIDS-associated oncogenesis. Cancer Treat. Res. 133, 141-162. doi: 10.1007/978-0-387-46816-7_5

Banerjee, S., Lu, J., Cai, Q., Saha, A., Jha, H. C., Dzeng, R. K., et al. (2013). The EBV latent antigen $3 \mathrm{C}$ inhibits apoptosis through targeted regulation of interferon regulatory factors 4 and 8. PLoS Pathog. 9:e1003314. doi: 10.1371/journal.ppat.1003314

Banerjee, S., Lu, J., Cai, Q., Sun, Z., Jha, H. C., and Robertson, E. S. (2014). EBNA3C augments Pim-1 mediated phosphorylation and degradation of p21 to promote B-cell proliferation. PLoS Pathog. 10:e1004304. doi: 10.1371/journal.ppat.1004304

Bechtel, D., Kurth, J., Unkel, C., and Kuppers, R. (2005). Transformation of BCRdeficient germinal-center B cells by EBV supports a major role of the virus in the pathogenesis of Hodgkin and posttransplantation lymphomas. Blood 106, 4345-4350. doi: 10.1182/blood-2005-06-2342

Bibas, M., and Antinori, A. (2009). EBV and HIV-Related Lymphoma. Mediterr. J. Hematol. Infect. Dis. 1:e2009032. doi: 10.4084/MJHID.2009.032

Boccellato, F., Anastasiadou, E., Rosato, P., Kempkes, B., Frati, L., Faggioni, A., et al. (2007). EBNA2 interferes with the germinal center phenotype by

\section{AUTHOR CONTRIBUTIONS}

All authors listed, have made substantial, direct and intellectual contribution to the work, and approved it for publication.

\section{ACKNOWLEDGMENTS}

This work was supported by National Cancer Institute at the National Institutes of Health public health service Grants CA137894, CA171979, CA174439, CA177423, P30-DK-050306, and P01-CA-174439 to ESR. We sincerely apologize to the authors whose important work could not be cited here due to space limitations.

downregulating BCL6 and TCL1 in non-Hodgkin's lymphoma cells. J. Virol. 81, 2274-2282. doi: 10.1128/JVI.01822-06

Borestrom, C., Forsman, A., Ruetschi, U., and Rymo, L. (2012). E2F1, ARID3A/Bright and Oct-2 factors bind to the Epstein-Barr virus C promoter, EBNA1 and oriP, participating in long-distance promoter-enhancer interactions. J. Gen. Virol. 93, 1065-1075. doi: 10.1099/vir.0.038752-0

Brady, G., MacArthur, G. J., and Farrell, P. J. (2007). Epstein-Barr virus and Burkitt lymphoma. J. Clin. Pathol. 60, 1397-1402.

Brooks, L., Yao, Q. Y., Rickinson, A. B., and Young, L. S. (1992). Epstein-Barr virus latent gene transcription in nasopharyngeal carcinoma cells: coexpression of EBNA1, LMP1, and LMP2 transcripts. J. Virol. 66, 2689-2697.

Bryant, H., and Farrell, P. J. (2002). Signal transduction and transcription factor modification during reactivation of Epstein-Barr virus from latency. J. Virol. 76, 10290-10298. doi: 10.1128/JVI.76.20.10290-10298.2002

Burkitt, D. P., and Nopmid. (1969). Etiology of Burkitt's lymphoma-an alternative hypothesis to a vectored virus. J. Natl. Cancer Inst. 42, 19-28.

Cancer Genome Atlas Research Network (2014). Comprehensive molecular characterization of gastric adenocarcinoma. Nature 513, 202-209. doi: 10.1038/nature13480

Cao, J. Y., Mansouri, S., and Frappier, L. (2012). Changes in the nasopharyngeal carcinoma nuclear proteome induced by the EBNA1 protein of Epstein-Barr virus reveal potential roles for EBNA1 in metastasis and oxidative stress responses. J. Virol. 86, 382-394. doi: 10.1128/JVI.05648-11

Cao, S. M., Simons, M. J., and Qian, C. N. (2011). The prevalence and prevention of nasopharyngeal carcinoma in China. Chin. J. Cancer 30, 114-119. doi: 10.5732/cjc.010.10377

Carbone, A., Gloghini, A., and Dotti, G. (2008). EBV-associated lymphoproliferative disorders: classification and treatment. Oncologist 13, 577-585. doi: 10.1634/theoncologist.2008-0036

Cardona, D. M., Layne, A., and Lagoo, A. S. (2012). Lymphomas of the gastrointestinal tract - pathophysiology, pathology, and differential diagnosis. Indian J. Pathol. Microbiol. 55, 1-16. doi: 10.4103/0377-4929.94847

Carter, K. L., Cahir-McFarland, E., and Kieff, E. (2002). Epstein-barr virus-induced changes in B-lymphocyte gene expression. J. Virol. 76, 10427-10436. doi: 10.1128/JVI.76.20.10427-10436.2002

Cavaliere, R., Petroni, G., Lopes, M. B., and Schiff, D. (2010). Primary central nervous system post-transplantation lymphoproliferative disorder: an international primary central nervous system lymphoma collaborative group report. Cancer 116, 863-870. doi: 10.1002/cncr.24834

Cesarman, E., and Mesri, E. A. (2007). Kaposi sarcoma-associated herpesvirus and other viruses in human lymphomagenesis. Curr. Top. Microbiol. Immunol. 312, 263-287.

Chang, L. K., Wei, T. T., Chiu, Y. F., Tung, C. P., Chuang, J. Y., Hung, S. K., et al. (2003). Inhibition of Epstein-Barr virus lytic cycle by (-)-epigallocatechin gallate. Biochem. Biophys. Res. Commun. 301, 1062-1068. doi: 10.1016/S0006291X(03)00067-6

Chang, S. S., Lo, Y. C., Chua, H. H., Chiu, H. Y., Tsai, S. C., Chen, J. Y., et al. (2008). Critical role of $\mathrm{p} 53$ in histone deacetylase inhibitor-induced Epstein-Barr virus Zta expression. J. Virol. 82, 7745-7751. doi: 10.1128/JVI.02717-07 
Chang, Y., Tung, C. H., Huang, Y. T., Lu, J., Chen, J. Y., and Tsai, C. H. (1999). Requirement for cell-to-cell contact in Epstein-Barr virus infection of nasopharyngeal carcinoma cells and keratinocytes. J. Virol. 73, 8857-8866.

Chau, C. M., Deng, Z., Kang, H., and Lieberman, P. M. (2008). Cell cycle association of the retinoblastoma protein $\mathrm{Rb}$ and the histone demethylase LSD1 with the Epstein-Barr virus latency promoter Cp. J. Virol. 82, 3428-3437. doi: 10.1128/JVI.01412-07

Chen, H., Huang, J., Wu, F. Y., Liao, G., Hutt-Fletcher, L., and Hayward, S. D. (2005). Regulation of expression of the Epstein-Barr virus BamHI-A rightward transcripts. J. Virol. 79, 1724-1733. doi: 10.1128/JVI.79.3.1724-1733.2005

Chen, J. (2012). Roles of the PI3K/Akt pathway in Epstein-Barr virus-induced cancers and therapeutic implications. World J. Virol. 1, 154-161. doi: 10.5501/wjv.v1.i6.154

Chen, X. Z., Chen, H., Castro, F. A., Hu, J. K., and Brenner, H. (2015). Epstein-Barr virus infection and gastric cancer: a systematic review. Medicine (Baltimore) 94:e792. doi: 10.1097/MD.0000000000000792

Cho, Y. G., Gordadze, A. V., Ling, P. D., and Wang, F. (1999). Evolution of two types of rhesus lymphocryptovirus similar to type 1 and type 2 Epstein-Barr virus. J. Virol. 73, 9206-9212.

Choudhuri, T., Verma, S. C., Lan, K., Murakami, M., and Robertson, E. S. (2007). The ATM/ATR signaling effector Chk2 is targeted by Epstein-Barr virus nuclear antigen 3C to release the G2/M cell cycle block. J. Virol. 81, 6718-6730. doi: 10.1128/JVI.00053-07

Cohen, J. I., Kimura, H., Nakamura, S., Ko, Y. H., and Jaffe, E. S. (2009). Epstein-Barr virus-associated lymphoproliferative disease in nonimmunocompromised hosts: a status report and summary of an international meeting, 8-9 September 2008. Ann. Oncol. 20, 1472-1482. doi: 10.1093/ annonc/mdp064

Dambaugh, T., Hennessy, K., Chamnankit, L., and Kieff, E. (1984). U2 region of Epstein-Barr virus DNA may encode Epstein-Barr nuclear antigen 2. Proc. Natl. Acad. Sci. U.S.A. 81, 7632-7636. doi: 10.1073/pnas.81.23.7632

Davies, M. L., Xu, S., Lyons-Weiler, J., Rosendorff, A., Webber, S. A., Wasil, L. R., et al. (2010). Cellular factors associated with latency and spontaneous EpsteinBarr virus reactivation in B-lymphoblastoid cell lines. Virology 400, 53-67. doi: 10.1016/j.virol.2010.01.002

De Laurenzi, V., Costanzo, A., Barcaroli, D., Terrinoni, A., Falco, M., Annicchiarico-Petruzzelli, M., et al. (1998). Two new p73 splice variants, gamma and delta, with different transcriptional activity. J. Exp. Med. 188, 1763-1768. doi: 10.1084/jem.188.9.1763

de Martel, C., Ferlay, J., Franceschi, S., Vignat, J., Bray, F., Forman, D., et al. (2012). Global burden of cancers attributable to infections in 2008: a review and synthetic analysis. Lancet Oncol. 13, 607-615. doi: 10.1016/S14702045(12)70137-7

De Paschale, M., and Clerici, P. (2012). Serological diagnosis of Epstein-Barr virus infection: problems and solutions. World J. Virol. 1, 31-43. doi: 10.5501/wjv.v1.i1.31

Delecluse, H. J., and Hammerschmidt, W. (2000). The genetic approach to the Epstein-Barr virus: from basic virology to gene therapy. Mol. Pathol. 53, 270-279. doi: 10.1136/mp.53.5.270

de-The, G. (1985). Epstein-Barr virus and Burkitt's lymphoma worldwide: the causal relationship revisited. IARC Sci. Publ. 60, 165-176.

Diaz, J. I., Edinger, M. G., Stoler, M., and Tubbs, R. R. (1993). Host tumor infiltrating lymphocytes in B cell non-Hodgkin's lymphomas. Leuk. Lymphoma 9, 85-90. doi: 10.3109/10428199309148508

Ding, L., Li, L., Yang, J., Zhou, S., Li, W., Tang, M., et al. (2007). Latent membrane protein 1 encoded by Epstein-Barr virus induces telomerase activity via p16INK4A/Rb/E2F1 and JNK signaling pathways. J. Med. Virol. 79, 1153-1163. doi: $10.1002 /$ jmv.20896

Dzeng, R. K., Jha, H. C., Lu, J., Saha, A., Banerjee, S., and Robertson, E. S. (2015). Small molecule growth inhibitors of human oncogenic gammaherpesvirus infected B-cells. Mol. Oncol. 9, 365-376. doi: 10.1016/j.molonc.2014.09.006

Edwards, R. H., Marquitz, A. R., and Raab-Traub, N. (2015). Changes in expression induced by Epstein-Barr virus LMP1-CTAR1: potential role of bcl3. MBio 6:e0441-15. doi: 10.1128/mBio.00441-15

Ekstrom Smedby, K., Vajdic, C. M., Falster, M., Engels, E. A., Martinez-Maza, O., Turner, J., et al. (2008). Autoimmune disorders and risk of non-Hodgkin lymphoma subtypes: a pooled analysis within the InterLymph consortium. Blood 111, 4029-4038. doi: 10.1182/blood-2007-10-119974
Engels, E. A. (2007). Infectious agents as causes of non-Hodgkin lymphoma. Cancer Epidemiol. Biomarkers. Prev. 16, 401-404. doi: 10.1158/1055-9965.EPI06-1056

Epstein, M. A., Achong, B. G., and Barr, Y. M. (1964). Virus particles in cultured lymphoblasts from Burkitt's lymphoma. Lancet 1, 702-703. doi: 10.1016/S01406736(64)91524-7

Everly, D. N. Jr., Mainou, B. A., and Raab-Traub, N. (2004). Induction of Id1 and Id 3 by latent membrane protein 1 of Epstein-Barr virus and regulation of p27/Kip and cyclin-dependent kinase 2 in rodent fibroblast transformation. J. Virol. 78, 13470-13478. doi: 10.1128/JVI.78.24.13470-13478.2004

Fagundes, C. P., Jaremka, L. M., Glaser, R., Alfano, C. M., Povoski, S. P., Lipari, A. M., et al. (2014). Attachment anxiety is related to Epstein-Barr virus latency. Brain Behav. Immun. 41, 232-238. doi: 10.1016/j.bbi.2014.04.002

Fahmi, H., Cochet, C., Hmama, Z., Opolon, P., and Joab, I. (2000). Transforming growth factor beta 1 stimulates expression of the Epstein-Barr virus BZLF1 immediate-early gene product ZEBRA by an indirect mechanism which requires the MAPK kinase pathway. J. Virol. 74, 5810-5818. doi: 10.1128/JVI.74. 13.5810-5818.2000

Feederle, R., Haar, J., Bernhardt, K., Linnstaedt, S. D., Bannert, H., Lips, H., et al. (2011). The members of an Epstein-Barr virus microRNA cluster cooperate to transform B lymphocytes. J. Virol. 85, 9801-9810. doi: 10.1128/JVI.05100-11

Fink, S. E., Gandhi, M. K., Nourse, J. P., Keane, C., Jones, K., Crooks, P., et al. (2014). A comprehensive analysis of the cellular and EBV-specific microRNAome in primary CNS PTLD identifies different patterns among EBVassociated tumors. Am. J. Transplant. 14, 2577-2587. doi: 10.1111/ajt.12858

Flavell, J. R., Baumforth, K. R., Wood, V. H., Davies, G. L., Wei, W., Reynolds, G. M., et al. (2008). Down-regulation of the TGF-beta target gene, PTPRK, by the Epstein-Barr virus encoded EBNA1 contributes to the growth and survival of Hodgkin lymphoma cells. Blood 111, 292-301.

Flavell, K. J., and Murray, P. G. (2000). Hodgkin's disease and the Epstein-Barr virus. Mol. Pathol. 53, 262-269. doi: 10.1136/mp.53.5.262

Forte, E., and Luftig, M. A. (2009). MDM2-dependent inhibition of p53 is required for Epstein-Barr virus B-cell growth transformation and infected-cell survival. J. Virol. 83, 2491-2499. doi: 10.1128/JVI.01681-08

Forte, E., Salinas, R. E., Chang, C., Zhou, T., Linnstaedt, S. D., Gottwein, E., et al. (2012). The Epstein-Barr Virus (EBV)-induced tumor suppressor microRNA MIR-34a is growth promoting in EBV-infected B cells. J. Virol. 86, 6889-6898. doi: 10.1128/JVI.07056-11

Frappier, L. (2012a). Contributions of Epstein-Barr nuclear antigen 1 (EBNA1) to cell immortalization and survival. Viruses 4, 1537-1547. doi: 10.3390/v4091537

Frappier, L. (2012b). The Epstein-Barr virus EBNA1 protein. Scientifica (Cairo) 2012, 438204. doi: 10.6064/2012/438204

Gershburg, E., and Pagano, J. S. (2005). Epstein-Barr virus infections: prospects for treatment. J. Antimicrob. Chemother. 56, 277-281. doi: 10.1093/jac/dki240

Giunco, S., Celeghin, A., Gianesin, K., Dolcetti, R., Indraccolo, S., and De Rossi, A. (2015). Cross talk between EBV and telomerase: the role of TERT and NOTCH2 in the switch of latent/lytic cycle of the virus. Cell Death Dis. 6:e1774. doi: $10.1038 /$ cddis. 2015.145

Givol, I., Givol, D., and Hughes, S. H. (1998). Overexpression of p21waf1/cip1 arrests the growth of chicken embryo fibroblasts that overexpress E2F1. Oncogene 16, 3115-3122. doi: 10.1038/sj.onc.1201849

Gorres, K. L., Daigle, D., Mohanram, S., and Miller, G. (2014). Activation and repression of Epstein-Barr virus and Kaposi's sarcoma-associated herpesvirus lytic cycles by short- and medium-chain fatty acids. J. Virol. 88, 8028-8044. doi: 10.1128/JVI.00722-14

Goswami, R., Gershburg, S., Satorius, A., and Gershburg, E. (2012). Protein kinase inhibitors that inhibit induction of lytic program and replication of EpsteinBarr virus. Antiviral. Res. 96, 296-304. doi: 10.1016/j.antiviral.2012.09.021

Gregory, C. D., Rowe, M., and Rickinson, A. B. (1990). Different EpsteinBarr virus-B cell interactions in phenotypically distinct clones of a Burkitt's lymphoma cell line. J. Gen. Virol. 71(Pt 7), 1481-1495. doi: 10.1099/0022-131771-7-1481

Gruffat, H., Batisse, J., Pich, D., Neuhierl, B., Manet, E., Hammerschmidt, W., et al. (2002a). Epstein-Barr virus mRNA export factor EB2 is essential for production of infectious virus. J. Virol. 76, 9635-9644. doi: 10.1128/JVI.76.19.96359644.2002

Gruffat, H., Manet, E., and Sergeant, A. (2002b). MEF2-mediated recruitment of class II HDAC at the EBV immediate early gene BZLF1 links latency 
and chromatin remodeling. EMBO Rep. 3, 141-146. doi: 10.1093/emboreports/kvf031

Gruhne, B., Sompallae, R., Marescotti, D., Kamranvar, S. A., Gastaldello, S., and Masucci, M. G. (2009). The Epstein-Barr virus nuclear antigen-1 promotes genomic instability via induction of reactive oxygen species. Proc. Natl. Acad. Sci. U.S.A. 106, 2313-2318. doi: 10.1073/pnas.0810619106

Grywalska, E., and Rolinski, J. (2015). Epstein-Barr virus-associated lymphomas. Semin. Oncol. 42, 291-303. doi: 10.1053/j.seminoncol.2014.12.030

Gstaiger, M., Jordan, R., Lim, M., Catzavelos, C., Mestan, J., Slingerland, J., et al. (2001). Skp2 is oncogenic and overexpressed in human cancers. Proc. Natl. Acad. Sci. U.S.A. 98, 5043-5048. doi: 10.1073/pnas.081474898

Gulley, M. L., Raphael, M., Lutz, C. T., Ross, D. W., and Raab-Traub, N. (1992). Epstein-Barr virus integration in human lymphomas and lymphoid cell lines. Cancer 70, 185-191. doi: 10.1002/1097-0142(19920701)70:1<185::AIDCNCR2820700129>3.0.CO;2-J

Gulley, M. L., and Tang, W. (2008). Laboratory assays for Epstein-Barr virus-related disease. J. Mol. Diagn. 10, 279-292. doi: 10.2353/jmoldx.2008. 080023

Gulley, M. L., and Tang, W. (2010). Using Epstein-Barr viral load assays to diagnose, monitor, and prevent posttransplant lymphoproliferative disorder. Clin. Microbiol. Rev. 23, 350-366. doi: 10.1128/CMR.00006-09

Gustafson, E. A., Chillemi, A. C., Sage, D. R., and Fingeroth, J. D. (1998). The Epstein-Barr virus thymidine kinase does not phosphorylate ganciclovir or acyclovir and demonstrates a narrow substrate specificity compared to the herpes simplex virus type 1 thymidine kinase. Antimicrob. Agents Chemother. 42, 2923-2931.

Haan, K. M., Aiyar, A., and Longnecker, R. (2001). Establishment of latent EpsteinBarr virus infection and stable episomal maintenance in murine B-cell lines. J. Virol. 75, 3016-3020. doi: 10.1128/JVI.75.6.3016-3020.2001

Halazonetis, T. D., and Kandil, A. N. (1991). Determination of the c-MYC DNA-binding site. Proc. Natl. Acad. Sci. U.S.A. 88, 6162-6166. doi: 10.1073/ pnas.88.14.6162

Halder, S., Murakami, M., Verma, S. C., Kumar, P., Yi, F., and Robertson, E. S. (2009). Early events associated with infection of Epstein-Barr virus infection of primary B-cells. PLoS ONE 4:e7214. doi: 10.1371/journal.pone.0007214

Harris-Arnold, A., Arnold, C. P., Schaffert, S., Hatton, O., Krams, S. M., Esquivel, C. O., et al. (2015). Epstein-Barr virus modulates host cell microRNA-194 to promote IL-10 production and B lymphoma cell survival. Am. J. Transplant. 15, 2814-2824. doi: 10.1111/ajt.13375

Henle, G., Henle, W., and Diehl, V. (1968). Relation of Burkitt's tumor-associated herpes-ytpe virus to infectious mononucleosis. Proc. Natl. Acad. Sci. U.S.A. 59, 94-101. doi: 10.1073/pnas.59.1.94

Herrmann, K., Frangou, P., Middeldorp, J., and Niedobitek, G. (2002). EpsteinBarr virus replication in tongue epithelial cells. J. Gen. Virol. 83, 2995-2998. doi: 10.1099/0022-1317-83-12-2995

Hislop, A. D., Taylor, G. S., Sauce, D., and Rickinson, A. B. (2007). Cellular responses to viral infection in humans: lessons from Epstein-Barr virus. Annu. Rev. Immunol. 25, 587-617. doi: 10.1146/annurev.immunol.25.022106. 141553

Hoang, A. T., Lutterbach, B., Lewis, B. C., Yano, T., Chou, T. Y., Barrett, J. F., et al. (1995). A link between increased transforming activity of lymphomaderived MYC mutant alleles, their defective regulation by p107, and altered phosphorylation of the c-Myc transactivation domain. Mol. Cell. Biol. 15, 4031-4042. doi: 10.1128/MCB.15.8.4031

Hofelmayr, H., Strobl, L. J., Marschall, G., Bornkamm, G. W., and ZimberStrobl, U. (2001). Activated Notch1 can transiently substitute for EBNA2 in the maintenance of proliferation of LMP1-expressing immortalized B cells. J. Virol. 75, 2033-2040. doi: 10.1128/JVI.75.5.2033-2040.2001

Hossain, M. S., Iqbal, M. S., Khan, M. A., Rabbani, M. G., Khatun, H., Munira, S., et al. (2014). Diagnosed hematological malignancies in Bangladesh a retrospective analysis of over 5000 cases from 10 specialized hospitals. BMC Cancer 14:438. doi: 10.1186/1471-2407-14-438

Hsieh, W. S., Lemas, M. V., and Ambinder, R. F. (1999). The biology of EpsteinBarr virus in post-transplant lymphoproliferative disease. Transpl. Infect. Dis. 1, 204-212. doi: 10.1034/j.1399-3062.1999.010308.x

Hui, K. F., Leung, Y. Y., Yeung, P. L., Middeldorp, J. M., and Chiang, A. K. (2014). Combination of SAHA and bortezomib up-regulates CDKN2A and CDKN1A and induces apoptosis of Epstein-Barr virus-positive Wp-restricted
Burkitt lymphoma and lymphoblastoid cell lines. Br. J. Haematol. 167, 639-650. doi: 10.1111/bjh.13089

Huo, X., Liu, S., Shao, T., Hua, H., Kong, Q., Wang, J., et al. (2014). GSK3 protein positively regulates type I insulin-like growth factor receptor through forkhead transcription factors FOXO1/3/4. J. Biol. Chem. 289, 24759-24770. doi: 10.1074/jbc.M114.580738

Iizasa, H., Nanbo, A., Nishikawa, J., Jinushi, M., and Yoshiyama, H. (2012). Epstein-Barr Virus (EBV)-associated gastric carcinoma. Viruses 4, 3420-3439. doi: $10.3390 / \mathrm{v} 4123420$

Inman, G. J., and Allday, M. J. (2000). Apoptosis induced by TGF-beta 1 in Burkitt's lymphoma cells is caspase 8 dependent but is death receptor independent. J. Immunol. 165, 2500-2510. doi: 10.4049/jimmunol.165. 5.2500

Inuzuka, H., Gao, D., Finley, L. W., Yang, W., Wan, L., Fukushima, H., et al. (2012). Acetylation-dependent regulation of Skp2 function. Cell 150, 179-193. doi: 10.1016/j.cell.2012.05.038

Issa, I., and Baydoun, H. (2009). Mesenteric panniculitis: various presentations and treatment regimens. World J. Gastroenterol. 15, 3827-3830. doi: 10.3748/wjg.15.3827

Jha, H. C., Aj, M., Saha, A., Banerjee, S., Lu, J., and Robertson, E. S. (2014). EpsteinBarr virus essential antigen EBNA3C attenuates $\mathrm{H} 2 \mathrm{AX}$ expression. J. Virol. 88, 3776-3788. doi: 10.1128/JVI.03568-13

Jha, H. C., Banerjee, S., and Robertson, E. S. (2016). The role of gammaherpesviruses in cancer pathogenesis. Pathogens 5:E18. doi: 10.3390/ pathogens5010018

Jha, H. C., Lu, J., Saha, A., Cai, Q., Banerjee, S., Prasad, M. A., et al. (2013a). EBNA3C-mediated regulation of aurora kinase B contributes to Epstein-Barr virus-induced B-cell proliferation through modulation of the activities of the retinoblastoma protein and apoptotic caspases. J. Virol. 87, 12121-12138. doi: 10.1128/JVI.02379-13

Jha, H. C., Mehta, D., Lu, J., El-Naccache, D., Shukla, S. K., Kovacsics, C., et al. (2015a). Gammaherpesvirus infection of human neuronal cells. MBio 6, e01844-15. doi: 10.1128/mBio.01844-15

Jha, H. C., Shukla, S. K., Lu, J., Aj, M. P., Banerjee, S., and Robertson, E. S. (2015b). Dissecting the contribution of EBNA3C domains important for EBVinduced B-cell growth and proliferation. Oncotarget 6, 30115-30129. doi: 10.18632/oncotarget.5002

Jha, H. C., Upadhyay, S. K., Prasaed, A. J. M., Lu, J., Cai, Q., Saha, A., et al. (2013b). H2AX phosphorylation is important for LANA-mediated Kaposi's sarcoma-associated herpesvirus episome persistence. J. Virol. 87, 5255-5269. doi: 10.1128/JVI.03575-12

Jha, H. C., Yang, K., El-Naccache, D. W., Sun, Z., and Robertson, E. S. (2015c). EBNA3C regulates p53 through induction of Aurora kinase B. Oncotarget 6, 5788-5803. doi: 10.18632/oncotarget. 3310

Jiang, J. H., Wang, N., Li, A., Liao, W. T., Pan, Z. G., Mai, S. J., et al. (2006). Hypoxia can contribute to the induction of the Epstein-Barr virus (EBV) lytic cycle. J. Clin. Virol. 37, 98-103. doi: 10.1016/j.jcv.2006.06.013

Jo, S. H., and Ren, R. (2012). IRF-4 suppresses BCR/ABL transformation of myeloid cells in a DNA binding-independent manner. J. Biol. Chem. 287, 1770-1778. doi: $10.1074 /$ jbc.M111.289728

Kaiser, C., Laux, G., Eick, D., Jochner, N., Bornkamm, G. W., and Kempkes, B. (1999). The proto-oncogene c-myc is a direct target gene of Epstein-Barr virus nuclear antigen 2. J. Virol. 73, 4481-4484.

Kanakry, J. A., and Ambinder, R. F. (2013). EBV-related lymphomas: new approaches to treatment. Curr. Treat. Options. Oncol. 14, 224-236. doi: 10.1007/s11864-013-0231-y

Kanda, A., Kawai, H., Suto, S., Kitajima, S., Sato, S., Takata, T., et al. (2005). AuroraB/AIM-1 kinase activity is involved in Ras-mediated cell transformation. Oncogene 24, 7266-7272. doi: 10.1038/sj.onc. 1208884

Kang, M. S., Lee, E. K., Soni, V., Lewis, T. A., Koehler, A. N., Srinivasan, V., et al. (2011). Roscovitine inhibits EBNA1 serine 393 phosphorylation, nuclear localization, transcription, and episome maintenance. J. Virol. 85, 2859-2868. doi: 10.1128/JVI.01628-10

Karslioglu, E., Kleinberger, J. W., Salim, F. G., Cox, A. E., Takane, K. K., Scott, D. K., et al. (2011). cMyc is a principal upstream driver of betacell proliferation in rat insulinoma cell lines and is an effective mediator of human beta-cell replication. Mol. Endocrinol. 25, 1760-1772. doi: 10.1210/me. 2011-1074 
Kelly, G. L., and Rickinson, A. B. (2007). Burkitt lymphoma: revisiting the pathogenesis of a virus-associated malignancy. Hematology Am. Soc. Hematol. Educ. Program. 2007, 277-284.

Kenney, S. C., and Mertz, J. E. (2014). Regulation of the latent-lytic switch in Epstein-Barr virus. Semin. Cancer Biol. 26, 60-68. doi: 10.1016/ j.semcancer.2014.01.002

Khan, G., and Hashim, M. J. (2014). Global burden of deaths from EpsteinBarr virus attributable malignancies 1990-2010. Infect. Agent Cancer 9:38. doi: 10.1186/1750-9378-9-38

Kirchmaier, A. L., and Sugden, B. (1997). Dominant-negative inhibitors of EBNA-1 of Epstein-Barr virus. J. Virol. 71, 1766-1775.

Knight, J. S., Sharma, N., and Robertson, E. S. (2005). Epstein-Barr virus latent antigen $3 \mathrm{C}$ can mediate the degradation of the retinoblastoma protein through an SCF cellular ubiquitin ligase. Proc. Natl. Acad. Sci. U.S.A. 102, 18562-18566. doi: 10.1073/pnas.0503886102

Komatsu, T. L., Rivero, E. R., Gallottini de Magalhaes, M. H., and Nunes, F. D. (2005). Epstein-Barr virus in oral hairy leukoplakia scrapes: identification by PCR. Braz. Oral. Res. 19, 317-321. doi: 10.1590/S1806-83242005000400015

Krol, A. D., le Cessie, S., Snijder, S., Kluin-Nelemans, J. C., Kluin, P. M., and Noordijk, E. M. (2003). Primary extranodal non-Hodgkin's lymphoma (NHL): the impact of alternative definitions tested in the Comprehensive Cancer Centre West population-based NHL registry. Ann. Oncol. 14, 131-139.

Kuppers, R., and Rajewsky, K. (1998). The origin of Hodgkin and Reed/Sternberg cells in Hodgkin's disease. Annu. Rev. Immunol. 16, 471-493. doi: 10.1146/annurev.immunol.16.1.471

Kuriyama, T., Kawano, N., Yamashita, K., and Ueda, A. (2014). Successful treatment of Rituximab-resistant Epstein-Barr virus-associated post-transplant lymphoproliferative disorder using R-CHOP. J. Clin. Exp. Hematop. 54, 149153. doi: $10.3960 /$ jslrt. 54.149

Kurth, J., Spieker, T., Wustrow, J., Strickler, G. J., Hansmann, L. M., Rajewsky, K., et al. (2000). EBV-infected B cells in infectious mononucleosis: viral strategies for spreading in the B cell compartment and establishing latency. Immunity 13, 485-495. doi: 10.1016/S1074-7613(00)00048-0

Kutok, J. L., and Wang, F. (2006). Spectrum of Epstein-Barr virus-associated diseases. Annu. Rev. Pathol. 1, 375-404. doi: 10.1146/annurev.pathol.1.110304. 100209

Lahoz, E. G., Xu, L., Schreiber-Agus, N., and DePinho, R. A. (1994). Suppression of Myc, but not E1a, transformation activity by Max-associated proteins, Mad and Mxi1. Proc. Natl. Acad. Sci. U.S.A. 91, 5503-5507. doi: 10.1073/pnas.91.12.5503

Lai, K. Y., Chou, Y. C., Lin, J. H., Liu, Y., Lin, K. M., Doong, S. L., et al. (2015). Maintenance of Epstein-Barr virus latent status by a novel mechanism, latent membrane protein 1-Induced interleukin-32, via the protein kinase c-delta Pathway. J. Virol. 89, 5968-5980. doi: 10.1128/JVI.00168-15

Laichalk, L. L., and Thorley-Lawson, D. A. (2005). Terminal differentiation into plasma cells initiates the replicative cycle of Epstein-Barr virus in vivo. J. Virol. 79, 1296-1307. doi: 10.1128/JVI.79.2.1296-1307.2005

Leao, M., Anderton, E., Wade, M., Meekings, K., and Allday, M. J. (2007). Epstein-barr virus-induced resistance to drugs that activate the mitotic spindle assembly checkpoint in Burkitt's lymphoma cells. J. Virol. 81, 248-260. doi: 10.1128/JVI.01096-06

Lewis, J. D. (2012). Risk of lymphoma in patients with inflammatory bowel disease. Gastroenterol. Hepatol. (N Y) 8, 45-47.

Lin, J., Jin, X., Page, C., Sondak, V. K., Jiang, G., and Reynolds, R. K. (2000). A modified p53 overcomes mdm2-mediated oncogenic transformation: a potential cancer therapeutic agent. Cancer Res. 60, 5895-5901.

Lin, J. C. (2003). Mechanism of action of glycyrrhizic acid in inhibition of EpsteinBarr virus replication in vitro. Antiviral. Res. 59, 41-47. doi: 10.1016/S01663542(03)00030-5

Lin, J. C., Cherng, J. M., Hung, M. S., Baltina, L. A., Baltina, L., and Kondratenko, R. (2008). Inhibitory effects of some derivatives of glycyrrhizic acid against Epstein-Barr virus infection: structure-activity relationships. Antiviral Res. 79, 6-11. doi: 10.1016/j.antiviral.2008.01.160

Liontos, M., Niforou, K., Velimezi, G., Vougas, K., Evangelou, K., Apostolopoulou, K., et al. (2009). Modulation of the E2F1-driven cancer cell fate by the DNA damage response machinery and potential novel E2F1 targets in osteosarcomas. Am. J. Pathol. 175, 376-391. doi: 10.2353/ajpath.2009. 081160
Liu, M. T., Chang, Y. T., Chen, S. C., Chuang, Y. C., Chen, Y. R., Lin, C. S., et al. (2005). Epstein-Barr virus latent membrane protein 1 represses p53mediated DNA repair and transcriptional activity. Oncogene 24, 2635-2646. doi: 10.1038/sj.onc.1208319

Lozano, R., Naghavi, M., Foreman, K., Lim, S., Shibuya, K., Aboyans, V., et al. (2012). Global and regional mortality from 235 causes of death for 20 age groups in 1990 and 2010: a systematic analysis for the Global Burden of Disease Study 2010. Lancet 380, 2095-2128. doi: 10.1016/S0140-6736(12)61728-0

Lu, J., Murakami, M., Verma, S. C., Cai, Q., Haldar, S., Kaul, R., et al. (2011). Epstein-Barr virus nuclear antigen 1 (EBNA1) confers resistance to apoptosis in EBV-positive B-lymphoma cells through up-regulation of survivin. Virology 410, 64-75. doi: 10.1016/j.virol.2010.10.029

Ma, J., Sigler, P. B., Xu, Z., and Karplus, M. (2000). A dynamic model for the allosteric mechanism of GroEL. J. Mol. Biol. 302, 303-313. doi: 10.1006/jmbi.2000.4014

Macfarlane, L. A., and Murphy, P. R. (2010). MicroRNA: biogenesis, function and role in cancer. Curr. Genomics 11, 537-561. doi: 10.2174/1389202107931 75895

Maddocks, O. D., Berkers, C. R., Mason, S. M., Zheng, L., Blyth, K., Gottlieb, E., et al. (2013). Serine starvation induces stress and p53-dependent metabolic remodelling in cancer cells. Nature 493, 542-546. doi: 10.1038/nature11743

Maier, S., Staffler, G., Hartmann, A., Hock, J., Henning, K., Grabusic, K., et al. (2006). Cellular target genes of Epstein-Barr virus nuclear antigen 2. J. Virol. 80, 9761-9771. doi: 10.1128/JVI.00665-06

Malinen, M., Jaaskelainen, T., Pelkonen, M., Heikkinen, S., Vaisanen, S., Kosma, V. M., et al. (2013). Proto-oncogene PIM-1 is a novel estrogen receptor target associating with high grade breast tumors. Mol. Cell. Endocrinol. 365, 270-276. doi: 10.1016/j.mce.2012.10.028

Mansouri, S., Pan, Q., Blencowe, B. J., Claycomb, J. M., and Frappier, L. (2014). Epstein-Barr virus EBNA1 protein regulates viral latency through effects on let-7 microRNA and dicer. J. Virol. 88, 11166-11177. doi: 10.1128/JVI.01785-14

Marquitz, A. R., Mathur, A., Chugh, P. E., Dittmer, D. P., and Raab-Traub, N. (2014). Expression profile of microRNAs in Epstein-Barr virus-infected AGS gastric carcinoma cells. J. Virol. 88, 1389-1393. doi: 10.1128/JVI.02662-13

Marquitz, A. R., Mathur, A., Edwards, R. H., and Raab-Traub, N. (2015). Host gene expression is regulated by two types of noncoding RNAs transcribed from the Epstein-Barr virus BamHI A rightward transcript region. J. Virol. 89, 11256-11268. doi: 10.1128/JVI.01492-15

Marsh, R. A., and Filipovich, A. H. (2011). Familial hemophagocytic lymphohistiocytosis and X-linked lymphoproliferative disease. Ann. N. Y. Acad. Sci. 1238, 106-121. doi: 10.1111/j.1749-6632.2011.06265.x

Martin, H. J., Lee, J. M., Walls, D., and Hayward, S. D. (2007). Manipulation of the toll-like receptor 7 signaling pathway by Epstein-Barr virus. J. Virol. 81, 9748-9758. doi: 10.1128/JVI.01122-07

Maynard, S., Schurman, S. H., Harboe, C., de Souza-Pinto, N. C., and Bohr, V. A. (2009). Base excision repair of oxidative DNA damage and association with cancer and aging. Carcinogenesis 30, 2-10. doi: 10.1093/carcin/bgn250

Merchant, M., Caldwell, R. G., and Longnecker, R. (2000). The LMP2A ITAM is essential for providing $B$ cells with development and survival signals in vivo. J. Virol. 74, 9115-9124. doi: 10.1128/JVI.74.19.9115-9124.2000

Mesri, E. A., Feitelson, M. A., and Munger, K. (2014). Human viral oncogenesis: a cancer hallmarks analysis. Cell Host Microbe 15, 266-282. doi: 10.1016/j.chom.2014.02.011

Middeldorp, J. M., Brink, A. A., van den Brule, A. J., and Meijer, C. J. (2003). Pathogenic roles for Epstein-Barr virus (EBV) gene products in EBV-associated proliferative disorders. Crit. Rev. Oncol. Hematol. 45, 1-36. doi: 10.1016/S10408428(02)00078-1

Mikawa, T., Maruyama, T., Okamoto, K., Nakagama, H., Lleonart, M. E., Tsusaka, T., et al. (2014). Senescence-inducing stress promotes proteolysis of phosphoglycerate mutase via ubiquitin ligase Mdm2. J. Cell Biol. 204, 729-745. doi: $10.1083 /$ jcb. 201306149

Miller, G., El-Guindy, A., Countryman, J., Ye, J., and Gradoville, L. (2007). Lytic cycle switches of oncogenic human gammaherpesviruses. Adv. Cancer Res. 97, 81-109. doi: 10.1016/S0065-230X(06)97004-3

Mochizuki, T., Kitanaka, C., Noguchi, K., Muramatsu, T., Asai, A., and Kuchino, Y. (1999). Physical and functional interactions between Pim-1 kinase and Cdc25A phosphatase. Implications for the Pim-1-mediated activation 
of the c-Myc signaling pathway. J. Biol. Chem. 274, 18659-18666. doi: 10.1074/jbc.274.26.18659

Moscato, M., Boon-Unge, K., and Restrepo, L. (2013). Enhancing brain lesions in a renal transplant patient. Neurohospitalist 3, 15-19. doi: $10.1177 / 1941874412459333$

Mosialos, G., Birkenbach, M., Yalamanchili, R., VanArsdale, T., Ware, C., and Kieff, E. (1995). The Epstein-Barr virus transforming protein LMP1 engages signaling proteins for the tumor necrosis factor receptor family. Cell 80, 389399. doi: 10.1016/0092-8674(95)90489-1

Murakami, M., Lan, K., Subramanian, C., and Robertson, E. S. (2005). Epstein-Barr virus nuclear antigen 1 interacts with $\mathrm{Nm} 23-\mathrm{H} 1$ in lymphoblastoid cell lines and inhibits its ability to suppress cell migration. J. Virol. 79, 1559-1568. doi: 10.1128/JVI.79.3.1559-1568.2005

Nickoloff, B. J., Qin, J. Z., Chaturvedi, V., Denning, M. F., Bonish, B., and Miele, L. (2002). Jagged-1 mediated activation of notch signaling induces complete maturation of human keratinocytes through NF-kappaB and PPARgamma. Cell Death Differ. 9, 842-855. doi: 10.1038/sj.cdd.4401036

Niedobitek, G. (2000). Epstein-Barr virus infection in the pathogenesis of nasopharyngeal carcinoma. Mol. Pathol. 53, 248-254. doi: 10.1136/mp.53.5.248

Noh, K. W., Park, J., Joo, E. H., Lee, E. K., Choi, E. Y., and Kang, M. S. (2016). ERK2 phosphorylation of EBNA1 serine 383 residue is important for EBNA1-dependent transactivation. Oncotarget 7, 25507-25515. doi: 10.18632 /oncotarget.8177

Odumade, O. A., Hogquist, K. A., and Balfour, H. H. Jr. (2011). Progress and problems in understanding and managing primary Epstein-Barr virus infections. Clin. Microbiol. Rev. 24, 193-209. doi: 10.1128/CMR.00044-10

Oh, J. K., and Weiderpass, E. (2014). Infection and cancer: global distribution and burden of diseases. Ann. Glob. Health 80, 384-392. doi: 10.1016/j.aogh.2014.09.013

O’Neil, J. D., Owen, T. J., Wood, V. H., Date, K. L., Valentine, R., Chukwuma, M. B., et al. (2008). Epstein-Barr virus-encoded EBNA1 modulates the AP-1 transcription factor pathway in nasopharyngeal carcinoma cells and enhances angiogenesis in vitro. J. Gen. Virol. 89, 2833-2842. doi: 10.1099/vir.0.2008/003392-0

Parkin, D. M. (2006). The global health burden of infection-associated cancers in the year 2002. Int. J. Cancer 118, 3030-3044. doi: 10.1002/ijc.21731

Pathmanathan, R., Prasad, U., Chandrika, G., Sadler, R., Flynn, K., and Raab-Traub, N. (1995). Undifferentiated, nonkeratinizing, and squamous cell carcinoma of the nasopharynx. Variants of Epstein-Barr virus-infected neoplasia. Am. J. Pathol. 146, 1355-1367.

Pegtel, D. M., Middeldorp, J., and Thorley-Lawson, D. A. (2004). Epstein-Barr virus infection in ex vivo tonsil epithelial cell cultures of asymptomatic carriers. J. Virol. 78, 12613-12624. doi: 10.1128/JVI.78.22.12613-12624.2004

Penkert, R. R., and Kalejta, R. F. (2011). Tegument protein control of latent herpesvirus establishment and animation. Herpesviridae 2:3. doi: 10.1186/20424280-2-3

Petrara, M. R., Giunco, S., Serraino, D., Dolcetti, R., and De Rossi, A. (2015). Posttransplant lymphoproliferative disorders: from epidemiology to pathogenesisdriven treatment. Cancer Lett. 369, 37-44. doi: 10.1016/j.canlet.2015.08.007

Pfeffer, S., Zavolan, M., Grasser, F. A., Chien, M., Russo, J. J., Ju, J., et al. (2004). Identification of virus-encoded microRNAs. Science 304, 734-736. doi: 10.1126/science.1096781

Pirollo, K. F., Hao, Z., Rait, A., Jang, Y. J., Fee, W. E. Jr., Ryan, P., et al. (1997). p53 mediated sensitization of squamous cell carcinoma of the head and neck to radiotherapy. Oncogene 14, 1735-1746. doi: 10.1038/sj.onc.1201116

Pisani, P., Parkin, D. M., Munoz, N., and Ferlay, J. (1997). Cancer and infection: estimates of the attributable fraction in 1990. Cancer Epidemiol. Biomarkers Prev. 6, 387-400.

Plaxco, K. W., Larson, S., Ruczinski, I., Riddle, D. S., Thayer, E. C., Buchwitz, B., et al. (2000). Evolutionary conservation in protein folding kinetics. J. Mol. Biol. 298, 303-312. doi: 10.1006/jmbi.1999.3663

Pope, J. H., Horne, M. K., and Scott, W. (1968). Transformation of foetal human keukocytes in vitro by filtrates of a human leukaemic cell line containing herpes-like virus. Int. J. Cancer 3, 857-866. doi: 10.1002/ijc.29 10030619

Prathapam, T., Kuhne, C., and Banks, L. (2002). Skip interacts with the retinoblastoma tumor suppressor and inhibits its transcriptional repression activity. Nucleic Acids Res. 30, 5261-5268. doi: 10.1093/nar/gkf658
Ragoczy, T., Heston, L., and Miller, G. (1998). The Epstein-Barr virus Rta protein activates lytic cycle genes and can disrupt latency in B lymphocytes. J. Virol. 72, 7978-7984.

Raver, R. M., Panfil, A. R., Hagemeier, S. R., and Kenney, S. C. (2013). The B-cellspecific transcription factor and master regulator Pax 5 promotes Epstein-Barr virus latency by negatively regulating the viral immediate early protein BZLF1. J. Virol. 87, 8053-8063. doi: 10.1128/JVI.00546-13

Reedman, B. M., and Klein, G. (1973). Cellular localization of an EpsteinBarr virus (EBV)-associated complement-fixing antigen in producer and non-producer lymphoblastoid cell lines. Int. J. Cancer 11, 499-520. doi: 10.1002/ijc.2910110302

Reimold, A. M., Iwakoshi, N. N., Manis, J., Vallabhajosyula, P., SzomolanyiTsuda, E., Gravallese, E. M., et al. (2001). Plasma cell differentiation requires the transcription factor XBP-1. Nature 412, 300-307. doi: 10.1038/35085509

Ren, X., McHale, C. M., Skibola, C. F., Smith, A. H., Smith, M. T., and Zhang, L. (2011). An emerging role for epigenetic dysregulation in arsenic toxicity and carcinogenesis. Environ. Health Perspect. 119, 11-19. doi: 10.1289/ehp.10 02114

Reusch, J. A., Nawandar, D. M., Wright, K. L., Kenney, S. C., and Mertz, J. E. (2015). Cellular differentiation regulator BLIMP1 induces Epstein-Barr virus lytic reactivation in epithelial and $B$ cells by activating transcription from both the R and Z promoters. J. Virol. 89, 1731-1743. doi: 10.1128/JVI.02781-14

Robertson, E. S., Grossman, S., Johannsen, E., Miller, C., Lin, J., Tomkinson, B., et al. (1995). Epstein-Barr virus nuclear protein 3C modulates transcription through interaction with the sequence-specific DNA-binding protein J kappa. J. Virol. 69, 3108-3116.

Robertson, E. S., Lin, J., and Kieff, E. (1996). The amino-terminal domains of Epstein-Barr virus nuclear proteins 3A, 3B, and 3C interact with RBPJ(kappa). J. Virol. 70, 3068-3074.

Robinson, A. R., Kwek, S. S., and Kenney, S. C. (2012). The B-cell specific transcription factor, Oct-2, promotes Epstein-Barr virus latency by inhibiting the viral immediate-early protein, BZLF1. PLoS Pathog. 8:e1002516. doi: 10.1371/journal.ppat.1002516

Rong, L., and Perelson, A. S. (2009). Modeling latently infected cell activation: viral and latent reservoir persistence, and viral blips in HIVinfected patients on potent therapy. PLoS Comput. Biol. 5:e1000533. doi: 10.1371/journal.pcbi.1000533

Rooney, C. M., Leen, A. M., Vera, J. F., and Heslop, H. E. (2014). T lymphocytes targeting native receptors. Immunol. Rev. 257, 39-55. doi: 10.1111/imr.12133

Ruf, I. K., and Sample, J. (1999). Repression of Epstein-Barr virus EBNA-1 gene transcription by pRb during restricted latency. J. Virol. 73, 7943-7951.

Saha, A., Halder, S., Upadhyay, S. K., Lu, J., Kumar, P., Murakami, M., et al. (2011). Epstein-Barr virus nuclear antigen 3C facilitates G1-S transition by stabilizing and enhancing the function of cyclin D1. PLoS Pathog. 7:e1001275. doi: 10.1371/journal.ppat.1001275

Saha, A., Jha, H. C., Upadhyay, S. K., and Robertson, E. S. (2015). Epigenetic silencing of tumor suppressor genes during in vitro EpsteinBarr virus infection. Proc. Natl. Acad. Sci. U.S.A. 112, E5199-E5207. doi: 10.1073/pnas. 1503806112

Saha, A., and Robertson, E. S. (2011). Epstein-Barr virus-associated B-cell lymphomas: pathogenesis and clinical outcomes. Clin. Cancer Res. 17, 30563063. doi: 10.1158/1078-0432.CCR-10-2578

Saridakis, V., Sheng, Y., Sarkari, F., Holowaty, M. N., Shire, K., Nguyen, T., et al. (2005). Structure of the p53 binding domain of HAUSP/USP7 bound to EpsteinBarr nuclear antigen 1 implications for EBV-mediated immortalization. Mol. Cell 18, 25-36. doi: 10.1016/j.molcel.2005.02.029

Seeger, C., and Sohn, J. A. (2014). Targeting hepatitis B virus with CRISPR/Cas9. Mol. Ther. Nucleic Acids 3:e216. doi: 10.1038/mtna.2014.68

Shaffer, A. L., Lin, K. I., Kuo, T. C., Yu, X., Hurt, E. M., Rosenwald, A., et al. (2002). Blimp-1 orchestrates plasma cell differentiation by extinguishing the mature B cell gene expression program. Immunity 17, 51-62. doi: 10.1016/S10747613(02)00335-7

Shair, K. H., Bendt, K. M., Edwards, R. H., Bedford, E. C., Nielsen, J. N., and Raab-Traub, N. (2007). EBV latent membrane protein 1 activates Akt, NFkappaB, and Stat3 in B cell lymphomas. PLoS Pathog. 3:e166. doi: 10.1371/journal.ppat.0030166

Shaknovich, R., Basso, K., Bhagat, G., Mansukhani, M., Hatzivassiliou, G., Murty, V. V., et al. (2006). Identification of rare Epstein-Barr virus 
infected memory B cells and plasma cells in non-monomorphic posttransplant lymphoproliferative disorders and the signature of viral signaling. Haematologica 91, 1313-1320.

Shannon-Lowe, C., Adland, E., Bell, A. I., Delecluse, H. J., Rickinson, A. B., and Rowe, M. (2009). Features distinguishing Epstein-Barr virus infections of epithelial cells and B cells: viral genome expression, genome maintenance, and genome amplification. J. Virol. 83, 7749-7760. doi: 10.1128/JVI.00108-09

Sharma, M., Mannan, R., Madhukar, M., Navani, S., Manjari, M., Bhasin, T. S., et al. (2014). Immunohistochemical (IHC) analysis of non-Hodgkin's lymphoma (NHL) spectrum according to WHO/REAL classification: a single centre experience from Punjab, India. J. Clin. Diagn. Res. 8, 46-49. doi: 10.7860/JCDR/2014/8173.3988

Shibata, D., Tokunaga, M., Uemura, Y., Sato, E., Tanaka, S., and Weiss, L. M. (1991). Association of Epstein-Barr virus with undifferentiated gastric carcinomas with intense lymphoid infiltration. Lymphoepithelioma-like carcinoma. Am. J. Pathol. 139, 469-474.

Sivachandran, N., Sarkari, F., and Frappier, L. (2008). Epstein-Barr nuclear antigen 1 contributes to nasopharyngeal carcinoma through disruption of PML nuclear bodies. PLoS Pathog. 4:e1000170. doi: 10.1371/journal.ppat.1000170

Speck, S. H., Chatila, T., and Flemington, E. (1997). Reactivation of Epstein-Barr virus: regulation and function of the BZLF1 gene. Trends Microbiol. 5, 399-405. doi: 10.1016/S0966-842X(97)01129-3

Spender, L. C., Cannell, E. J., Hollyoake, M., Wensing, B., Gawn, J. M., Brimmell, M., et al. (1999). Control of cell cycle entry and apoptosis in B lymphocytes infected by Epstein-Barr virus. J. Virol. 73, 4678-4688.

Spender, L. C., and Inman, G. J. (2011). Inhibition of germinal centre apoptotic programmes by epstein-barr virus. Adv. Hematol. 2011:829525. doi: $10.1155 / 2011 / 829525$

Stuhlmann-Laeisz, C., Borchert, A., Quintanilla-Martinez, L., Hoeller, S., Tzankov, A., Oschlies, I., et al. (2016). In Europe expression of EBNA2 is associated with poor survival in EBV-positive diffuse large B-cell lymphoma of the elderly. Leuk. Lymphoma 57, 39-44. doi: 10.3109/10428194.2015.1040014

Subramanian, C., Cotter, M. A. II, and Robertson, E. S. (2001). Epstein-Barr virus nuclear protein EBNA-3C interacts with the human metastatic suppressor Nm23-H1: a molecular link to cancer metastasis. Nat. Med. 7, 350-355. doi: $10.1038 / 85499$

Subramanian, D., Bunjobpol, W., and Sabapathy, K. (2015). Interplay between TAp73 protein and selected activator protein-1 (AP-1) family members promotes AP-1 target gene activation and cellular growth. J. Biol. Chem. 290, 18636-18649. doi: 10.1074/jbc.M115.636548

Sun, J., Hu, C., Zhu, Y., Sun, R., Fang, Y., Fan, Y., et al. (2015). LMP1 increases expression of NADPH oxidase (NOX) and its regulatory subunit p22 in NP69 nasopharyngeal cells and makes them sensitive to a treatment by a NOX inhibitor. PLoS ONE 10:e0134896. doi: 10.1371/journal.pone.0134896

Tanner, J. E., and Alfieri, C. (2001). The Epstein-Barr virus and post-transplant lymphoproliferative disease: interplay of immunosuppression, EBV, and the immune system in disease pathogenesis. Transpl. Infect. Dis. 3, 60-69. doi: 10.1034/j.1399-3062.2001.003002060.x

Tao, Q., Robertson, K. D., Manns, A., Hildesheim, A., and Ambinder, R. F. (1998). Epstein-Barr virus (EBV) in endemic Burkitt's lymphoma: molecular analysis of primary tumor tissue. Blood 91, 1373-1381.

Taylor, C. R., Russell, R., Lukes, R. J., and Davis, R. L. (1978). An immunohistological study of immunoglobulin content of primary central nervous system lymphomas. Cancer 41, 2197-2205. doi: 10.1002/1097-0142 (197806)41:6<2197::AID-CNCR2820410619>3.0.CO;2-2

Thompson, M. P., and Kurzrock, R. (2004). Epstein-Barr virus and cancer. Clin. Cancer Res. 10, 803-821. doi: 10.1158/1078-0432.CCR-0670-3

Thorley-Lawson, D. A. (2001). Epstein-Barr virus: exploiting the immune system. Nat. Rev. Immunol. 1, 75-82. doi: 10.1038/35095584

Tomkinson, B., Robertson, E., and Kieff, E. (1993). Epstein-Barr virus nuclear proteins EBNA-3A and EBNA-3C are essential for B-lymphocyte growth transformation. J. Virol. 67, 2014-2025.

Torre, L. A., Bray, F., Siegel, R. L., Ferlay, J., Lortet-Tieulent, J., and Jemal, A. (2015). Global cancer statistics, 2012. CA Cancer J. Clin. 65, 87-108. doi: $10.3322 /$ caac. 21262

Tsao, S. W., Tsang, C. M., To, K. F., and Lo, K. W. (2015). The role of Epstein-Barr virus in epithelial malignancies. J. Pathol. 235, 323-333. doi: 10.1002/path.4448
Tsimbouri, P., Drotar, M. E., Coy, J. L., and Wilson, J. B. (2002). bcl-xL and RAG genes are induced and the response to IL-2 enhanced in EmuEBNA-1 transgenic mouse lymphocytes. Oncogene 21, 5182-5187. doi: 10.1038/sj.onc.1205490

Tsurumi, T., Fujita, M., and Kudoh, A. (2005). Latent and lytic Epstein-Barr virus replication strategies. Rev. Med. Virol. 15, 3-15. doi: 10.1002/rmv.441

Tursiella, M. L., Bowman, E. R., Wanzeck, K. C., Throm, R. E., Liao, J., Zhu, J., et al. (2014). Epstein-Barr virus nuclear antigen 3A promotes cellular proliferation by repression of the cyclin-dependent kinase inhibitor p21WAF1/CIP1. PLoS Pathog. 10:e1004415. doi: 10.1371/journal.ppat.1004415

Tzellos, S., Correia, P. B., Karstegl, C. E., Cancian, L., Cano-Flanagan, J., McClellan, M. J., et al. (2014). A single amino acid in EBNA-2 determines superior B lymphoblastoid cell line growth maintenance by Epstein-Barr virus type 1 EBNA-2. J. Virol. 88, 8743-8753. doi: 10.1128/JVI.01000-14

Valenzuela-Salas, B., Dean-Ferrer, A., and Alamillos-Granados, F. J. (2010). Burkitt's lymphoma: a child's case presenting in the maxilla. Clinical and radiological aspects. Med. Oral. Patol. Oral. Cir. Bucal 15, e479-e482. doi: 10.4317/medoral.15.e479

Vockerodt, M., Yap, L. F., Shannon-Lowe, C., Curley, H., Wei, W., Vrzalikova, K., et al. (2015). The Epstein-Barr virus and the pathogenesis of lymphoma. J. Pathol. 235, 312-322. doi: 10.1002/path.4459

Vrzalikova, K., Vockerodt, M., Leonard, S., Bell, A., Wei, W., Schrader, A., et al. (2011). Down-regulation of BLIMPlalpha by the EBV oncogene, LMP-1, disrupts the plasma cell differentiation program and prevents viral replication in B cells: implications for the pathogenesis of EBV-associated B-cell lymphomas. Blood 117, 5907-5917. doi: 10.1182/blood-2010-09-307710

Walling, D. M., Flaitz, C. M., Nichols, C. M., Hudnall, S. D., and Adler-Storthz, K. (2001). Persistent productive Epstein-Barr virus replication in normal epithelial cells in vivo. J. Infect. Dis. 184, 1499-1507. doi: 10.1086/323992

Wang, G. L., Salisbury, E., Shi, X., Timchenko, L., Medrano, E. E., and Timchenko, N. A. (2008). HDAC1 cooperates with C/EBPalpha in the inhibition of liver proliferation in old mice. J. Biol. Chem. 283, 26169-26178. doi: $10.1074 /$ jbc.M803544200

Weniger, M. A., and Kuppers, R. (2016). NF-kappaB deregulation in Hodgkin lymphoma. Semin. Cancer Biol. 39, 32-39. doi: 10.1016/j.semcancer. 2016.05.001

Whitehurst, C. B., Li, G., Montgomery, S. A., Montgomery, N. D., Su, L. and Pagano, J. S. (2015). Knockout of Epstein-Barr virus BPLF1 retards B-cell transformation and lymphoma formation in humanized mice. MBio 6: e01574-15.

Wright, D. H. (1971). Burkitt's lymphoma: a review of the pathology, immunology, and possible etiologic factors. Pathol. Annu. 6, 337-363.

Wu, Y., Maruo, S., Yajima, M., Kanda, T., and Takada, K. (2007). Epstein-Barr virus (EBV)-encoded RNA 2 (EBER2) but not EBER1 plays a critical role in EBV-induced B-cell growth transformation. J. Virol. 81, 11236-11245. doi: 10.1128/JVI.00579-07

Xu, D., Meyer, F., Ehlers, E., Blasnitz, L., and Zhang, L. (2011). Interferon regulatory factor 4 (IRF-4) targets IRF-5 to regulate Epstein-Barr virus transformation. J. Biol. Chem. 286, 18261-18267. doi: 10.1074/jbc.M110. 210542

Yajima, M., Kanda, T., and Takada, K. (2005). Critical role of EpsteinBarr Virus (EBV)-encoded RNA in efficient EBV-induced B-lymphocyte growth transformation. J. Virol. 79, 4298-4307. doi: 10.1128/JVI.79.7.42984307.2005

Yamamoto, N., Takizawa, T., Iwanaga, Y., Shimizu, N., and Yamamoto, N. (2000). Malignant transformation of B lymphoma cell line BJAB by Epstein-Barr virus-encoded small RNAs. FEBS Lett. 484, 153-158. doi: 10.1016/S00145793(00)02145-1

Ye, F., Lei, X., and Gao, S. J. (2011). Mechanisms of Kaposi's sarcomaassociated herpesvirus latency and reactivation. Adv. Virol. 2011:193860. doi: $10.1155 / 2011 / 193860$

Young, L. S., and Dawson, C. W. (2014). Epstein-Barr virus and nasopharyngeal carcinoma. Chin. J. Cancer 33, 581-590. doi: 10.5732/cjc.014.10197

Young, L. S., and Rickinson, A. B. (2004). Epstein-Barr virus: 40 years on. Nat. Rev. Cancer 4, 757-768. doi: 10.1038/nrc1452

Yuen, K. S., Chan, C. P., Wong, N. H., Ho, C. H., Ho, T. H., Lei, T., et al. (2015). CRISPR/Cas9-mediated genome editing of Epstein-Barr virus in human cells. J. Gen. Virol. 96, 626-636. doi: 10.1099/jgv.0.000012 
Zalani, S., Coppage, A., Holley-Guthrie, E., and Kenney, S. (1997). The cellular YY1 transcription factor binds a cis-acting, negatively regulating element in the Epstein-Barr virus BRLF1 promoter. J. Virol. 71, 3268-3274.

Zebboudj, A., Maroui, M. A., Dutrieux, J., Touil-Boukoffa, C., Bourouba, M., Chelbi-Alix, M. K., et al. (2014). Sodium arsenite induces apoptosis and Epstein-Barr virus reactivation in lymphoblastoid cells. Biochimie 107(Pt. B), 247-256. doi: 10.1016/j.biochi.2014.09.002

Zhang, G., Zong, J., Lin, S., Verhoeven, R. J., Tong, S., Chen, Y., et al. (2015). Circulating Epstein-Barr virus microRNAs miR-BART7 and miR-BART13 as biomarkers for nasopharyngeal carcinoma diagnosis and treatment. Int. J. Cancer 136, E301-E312. doi: 10.1002/ijc.29206

Zhang, L., and Pagano, J. S. (2001). Interferon regulatory factor 7: a key cellular mediator of LMP-1 in EBV latency and transformation. Semin. Cancer Biol. 11, 445-453. doi: 10.1006/scbi.2001.0411

Zhang, Z., Wang, H., Li, M., Rayburn, E. R., Agrawal, S., and Zhang, R. (2005). Stabilization of E2F1 protein by MDM2 through the E2F1 ubiquitination pathway. Oncogene 24, 7238-7247. doi: 10.1038/sj.onc.1208814

Zhao, Y., Xu, D., Jiang, Y., and Zhang, L. (2010). Dual functions of interferon regulatory factors $7 \mathrm{C}$ in Epstein-Barr virus-mediated transformation of human B lymphocytes. PLoS ONE 5:e9459. doi: 10.1371/journal.pone.00 09459

Zhou, J., Chau, C. M., Deng, Z., Shiekhattar, R., Spindler, M. P., Schepers, A., et al. (2005). Cell cycle regulation of chromatin at an origin of DNA replication. EMBO J. 24, 1406-1417. doi: 10.1038/sj.emboj.7600609

Zhou, S., Fujimuro, M., Hsieh, J. J., Chen, L., and Hayward, S. D. (2000). A role for SKIP in EBNA2 activation of CBF1-repressed promoters. J. Virol. 74, 1939-1947. doi: 10.1128/JVI.74.4.1939-1947.2000

Conflict of Interest Statement: The authors declare that the research was conducted in the absence of any commercial or financial relationships that could be construed as a potential conflict of interest.

Copyright (c) 2016 Jha, Pei and Robertson. This is an open-access article distributed under the terms of the Creative Commons Attribution License (CC BY). The use, distribution or reproduction in other forums is permitted, provided the original author(s) or licensor are credited and that the original publication in this journal is cited, in accordance with accepted academic practice. No use, distribution or reproduction is permitted which does not comply with these terms. 